\title{
SOEP
}

SOEPpapers

SOEPpapers
on Multidisciplinary Panel Data Research
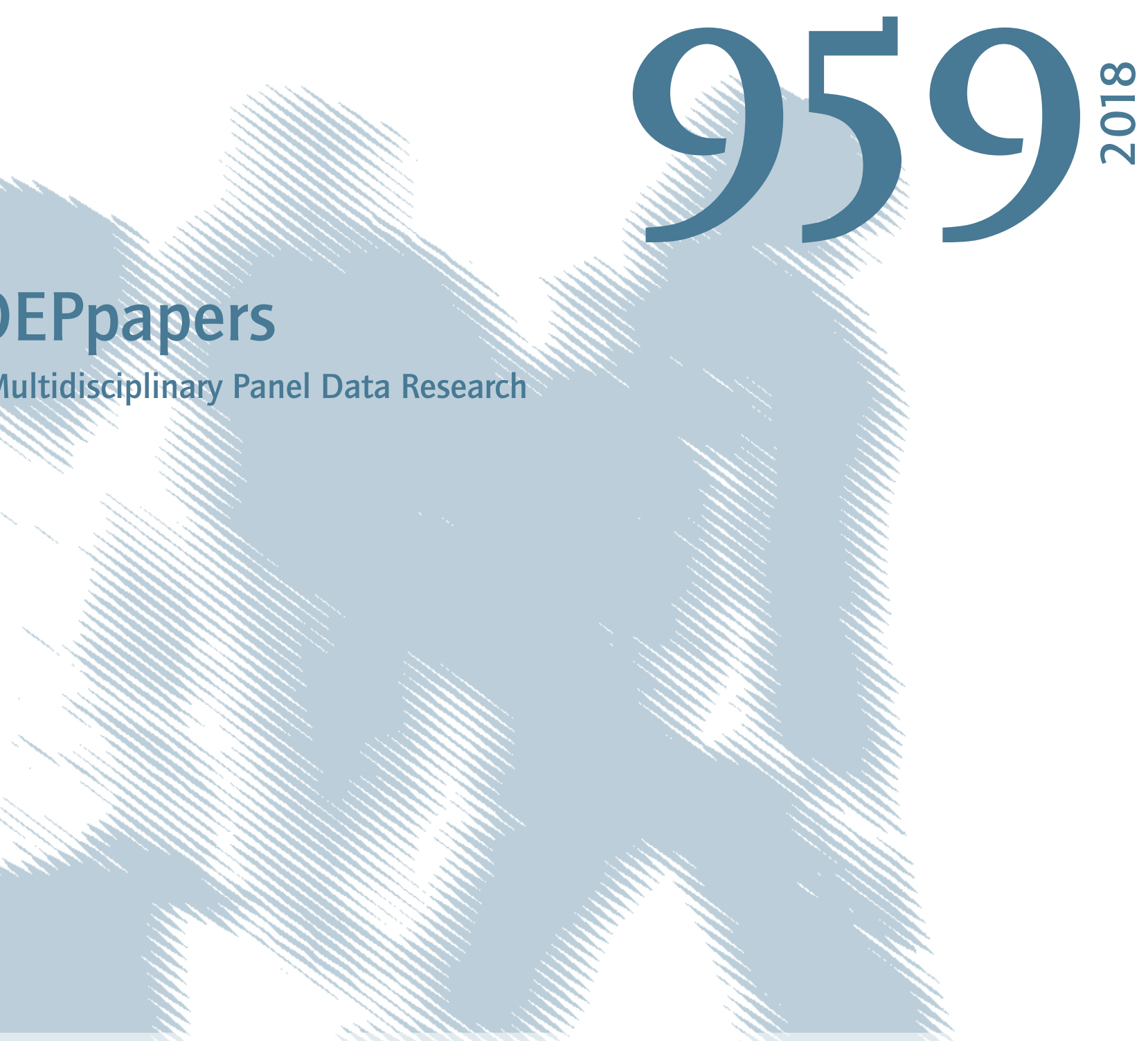

\section{Opportunity versus Necessity Entrepreneurship: Two Components of Business Creation}


This series presents research findings based either directly on data from the German SocioEconomic Panel study (SOEP) or using SOEP data as part of an internationally comparable data set (e.g. CNEF, ECHP, LIS, LWS, CHER/PACO). SOEP is a truly multidisciplinary household panel study covering a wide range of social and behavioral sciences: economics, sociology, psychology, survey methodology, econometrics and applied statistics, educational science, political science, public health, behavioral genetics, demography, geography, and sport science.

The decision to publish a submission in SOEPpapers is made by a board of editors chosen by the DIW Berlin to represent the wide range of disciplines covered by SOEP. There is no external referee process and papers are either accepted or rejected without revision. Papers appear in this series as works in progress and may also appear elsewhere. They often represent preliminary studies and are circulated to encourage discussion. Citation of such a paper should account for its provisional character. A revised version may be requested from the author directly.

Any opinions expressed in this series are those of the author(s) and not those of DIW Berlin. Research disseminated by DIW Berlin may include views on public policy issues, but the institute itself takes no institutional policy positions.

The SOEPpapers are available at http://www.diw.de/soeppapers

\section{Editors:}

Jan Goebel (Spatial Economics)

Stefan Liebig (Sociology)

David Richter (Psychology)

Carsten Schröder (Public Economics)

Jürgen Schupp (Sociology)

Conchita D'Ambrosio (Public Economics, DIW Research Fellow)

Denis Gerstorf (Psychology, DIW Research Fellow)

Elke Holst (Gender Studies, DIW Research Director)

Martin Kroh (Political Science, Survey Methodology)

Jörg-Peter Schräpler (Survey Methodology, DIW Research Fellow)

Thomas Siedler (Empirical Economics, DIW Research Fellow)

C. Katharina Spieß (Education and Family Economics)

Gert G. Wagner (Social Sciences)

ISSN: 1864-6689 (online)

German Socio-Economic Panel (SOEP)

DIW Berlin

Mohrenstrasse 58

10117 Berlin, Germany

Contact: soeppapers@diw.de

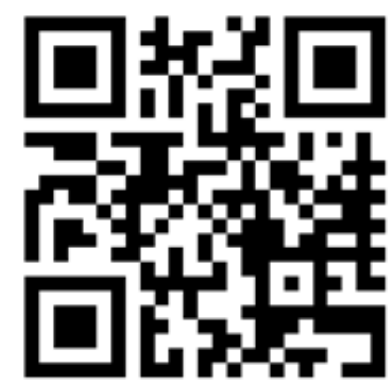




\title{
Opportunity versus Necessity Entrepreneurship: Two Components of Business Creation
}

\author{
Robert W. Fairlie \\ University of California, Santa Cruz \\ NBER \\ (rfairlie@ucsc.edu) \\ Frank M. Fossen \\ University of Nevada, Reno \\ DIW Berlin \\ IZA \\ (ffossen@unr.edu)
}

January 11, 2018

\begin{abstract}
A common finding in the entrepreneurship literature is that business creation increases in recessions. This counter-cyclical pattern is examined by separating business creation into two components: "opportunity" and "necessity" entrepreneurship. Although there is general agreement in the previous literature on the conceptual distinction between these two factors driving entrepreneurship, there are many challenges to creating a definition that is both objective and empirically feasible. We propose an operational definition of opportunity versus necessity entrepreneurship using readily available nationally representative data. We create a distinction between the two types of entrepreneurship based on the entrepreneur's prior work status that is consistent with the standard theoretical economic model of entrepreneurship. Using this definition we document that "opportunity" entrepreneurship is pro-cyclical and "necessity" entrepreneurship is counter-cyclical. We also find that "opportunity" vs. "necessity" entrepreneurship is associated with the creation of more growth-oriented businesses. The operational distinction proposed here may be useful for future research in entrepreneurship.
\end{abstract}

We thank Marco Caliendo, Marie Mora, Jeremy Moulton, Barbara Robles, Ting Zhang, and participants at the 2017 ASSA/AEA Annual Meeting in Chicago, IL, for helpful comments and suggestions. Fairlie also thanks Stanford University (SIEPR) for support as a visiting scholar while working on the project. 


\section{Introduction}

Although the U.S. unemployment rate rose to over 10 percent in the "Great Recession" and the economic contraction was generally considered the worst since the Great Depression, business creation actually increased steadily during the recession (Fairlie 2013). Business creation was also lower throughout the preceding period of unusually strong economic growth, commonly referred to as the "Roaring 90s." Similar patterns were found for the United Kingdom (Bell and Blanchflower 2011), and previous research on the general relationship between unemployment and entrepreneurship provides mixed results with many studies showing positive relationships, negative relationships, and zero relationships (Parker 2009). ${ }^{1}$ One potential reason for the lack of finding an unambiguous relationship between economic conditions and entrepreneurship is that there are two underlying components to business creation: one that is pro-cyclical and one that is counter-cyclical. Indeed, one topic of research in entrepreneurship that has drawn a substantial amount of attention in recent years is identifying two different motivations for starting a business: "opportunity" entrepreneurship and "necessity" entrepreneurship. ${ }^{2}$ The basic distinction is that some entrepreneurs create businesses when they see a business opportunity whereas other entrepreneurs are forced into starting a business out of necessity because of the lack of other options in the labor market. ${ }^{3}$

\footnotetext{
${ }^{1}$ Using a cross-country panel of 22 OECD countries from 1972 to 2007 Koellinger and Thurik (2012) find that the entrepreneurial cycle is positively affected by the national unemployment cycle. Congregado et al. (2012) and Fritsch et al. (2015) report evidence of overall counter-cyclical entrepreneurship rates in Spain and Germany.

${ }^{2}$ A large number of recent papers mention the distinction, see for example Wennekers et al. (2005), Bergmann and Sternberg (2007), Ho and Wong (2007), Van Stel et al. (2007), Acs and Amorós (2008), Bjørnskov and Foss (2008), McMullen et al. (2008), Block and Koellinger (2009), Block and Sandner (2009), Caliendo and Kritikos (2009, 2010), Koellinger and Minniti (2009), Stephen et al. (2009), Block and Wagner (2010), Kautonen and Palmroos (2010), Stephan and Uhlaner (2010), Terjesen and Amorós (2010), Giacomin et al. (2011), Pinillos and Reyes (2011), Serida and Morales (2011), Dawson and Henley (2012), Nissan et al. (2012), Fossen and Buettner (2013), Van der Zwang et al. (2016), and Calderon et al. (2017).

${ }^{3}$ The terms "pull" vs "push" entrepreneurship or "disadvantaged" entrepreneurship have also been used in the previous literature to express roughly similar ideas. The term "innovative" entrepreneurship is related to opportunity entrepreneurship (Block et al. 2016).
} 
In this paper, we propose a definition of opportunity and necessity entrepreneurship that can be used in future empirical research. In our opinion, a useful operational definition needs to meet four criteria:

i) It has to be consistent with the standard theoretical economic model of entrepreneurship.

ii) It has to be defined ex ante.

iii) It has to be readily available in nationally representative datasets.

iv) It has to be objectively defined and not open to interpretation by survey respondents.

To satisfy these four criteria for classifying entrepreneurs into opportunity versus necessity entrepreneurship, we propose using initial unemployment status. Individuals who are initially unemployed before starting businesses are defined as "necessity" entrepreneurs, and individuals who are wage/salary workers, enrolled in school or college, or are not actively seeking a job are defined as "opportunity" entrepreneurs. Although it is difficult to cleanly dichotomize the two types of entrepreneurship, the proposed distinction closely matches the theoretical concepts, is determined ex ante (i.e., before starting the business), and is objectively defined. Prior unemployment status is also often available in both panel and cross-sectional datasets. Panel datasets will typically have month-to-month or year-to-year information on unemployment, wage/salary work and business ownership. Cross-sectional datasets sometimes provide information on the labor force state just prior to the current labor force state.

An early attempt at creating a working definition of opportunity vs. necessity entrepreneurship was provided by the Global Entrepreneurship Monitor (GEM). GEM relies on self-classification based on a specially designed survey question: "Are you involved in this startup to take advantage of a business opportunity or because you have no better choices for work?" But, as we discuss in Section 3, there are concerns that this definition is available only in a few 
datasets, subjective, and may depend on the success of the business launch instead of pre-launch motivations.

In addition to discussing the proposed operational definitions of opportunity and necessity entrepreneurship in detail, we demonstrate how these definitions are motivated by the classic theoretical economic model of entrepreneurship. Using microdata from nationally-representative and widely used sources we also show that opportunity entrepreneurship generally moves procyclically and necessity entrepreneurship clearly moves counter-cyclically. We document these patterns at the national and local labor market levels for both the United States and Germany. Finally, we present findings indicating that opportunity vs. necessity entrepreneurship is positively associated with the creation of more growth oriented businesses. The proposed operational definition may be useful for future research on entrepreneurship.

\section{Theoretical Motivations}

We first show how distinguishing between opportunity and necessity entrepreneurship by prior unemployment status is motivated by theory. Theoretical models of the choice to become self-employed in economics are generally based on a comparison of potential income from business ownership and wage and salary work. In the classic economic model by Evans and Jovanovic (1989) individuals can obtain the following income, $\mathrm{Y}^{\mathrm{W}}$, from the wage and salary sector:

(2.1) $\mathrm{Y}^{\mathrm{W}}=\mathrm{w}+\mathrm{rA}$,

where $\mathrm{w}$ is the wage earned (earnings) in the market, $\mathrm{r}$ is the interest rate, and $\mathrm{A}$ represents the consumer's assets. Income in the self-employment sector, $\mathrm{Y}^{\mathrm{SE}}$, is defined as:

(2.2) $\mathrm{Y}^{\mathrm{SE}}=\theta \mathrm{f}(\mathrm{k}) \varepsilon+\mathrm{r}(\mathrm{A}-\mathrm{k})$ 
where $\theta$ is entrepreneurial ability, $\mathrm{f}($.$) is a production function whose only input is capital, \varepsilon$ is a random component to the production process, and $\mathrm{k}$ is the amount of capital employed in the business. Individuals choose to become self-employed if the potential earnings from selfemployment and investing remaining personal wealth after using it for startup capital is higher than the potential income from wage and salary work and investing personal wealth.

Two clarifications are needed in the model to facilitate the discussion of opportunity vs. necessity entrepreneurship. First, in (2.1) it is important to note that $\mathrm{w}$ is total earnings of which employment is a major component. Second, $\theta \mathrm{f}(\mathrm{k}) \varepsilon$ in (2.2) captures production measured in profits and not in the quantity produced. Thus, for example, $\varepsilon$ might capture a random demand shock instead of, or in addition to, a random shock to production. Note that in both cases, all components of income are measured in dollars.

This simple theoretical model is useful for identifying the two components of business creation. Necessity entrepreneurship is generally thought of as business creation in the face of limited alternative opportunities. In this model, this would imply that $\mathrm{Y}^{\mathrm{W}}$ is low or suffered an adverse shock. Given that there is downward wage rigidity in the labor market, the primary cause of low earnings in the wage and salary sector will more commonly be through unemployment and not a reduction in wages. In this way, we can associate unemployment with necessity entrepreneurship.

Opportunity entrepreneurship is generally thought of as business creation when there is an entrepreneurial opportunity. In this case, $\mathrm{Y}^{\mathrm{SE}}$ is high or experienced a positive shock. In examining (2.2) there are several possible factors resulting in opportunity entrepreneurship. First, there could be a positive random shock to production (measured in profits). Consumer and firm demand for products and services provided by startups might increase resulting in higher $\varepsilon$. Another possibility 
is that an entrepreneur might discover a better production method resulting in a larger $\mathrm{f}(\mathrm{k})$ for any value of $\mathrm{k}$. Third, entrepreneurial ability may be high or change. Some individuals might take advantage of higher or increased entrepreneurial ability. Finally, capital may become more available or cheaper resulting in expanded opportunities for business creation. All of these cases are forms of opportunity entrepreneurship.

It is important to note, however, that this discussion holds everything constant, which is difficult to find in the real world. It is rare that one factor affecting either necessity or opportunity entrepreneurship will change in isolation. For example, factors that lead to high levels of unemployment also often lead to limited entrepreneurial opportunities. One of the main effects of recessions is that they reduce consumer and firm demand for products and services provided by startups, thus decreasing potential entrepreneurial earnings, $\mathrm{Y}^{\mathrm{SE}}$. Recessions may also reduce total wealth, A, which in turn would lower the likelihood of entrepreneurship. In the presence of liquidity constraints, lower levels of wealth may make it more difficult for entrepreneurs to find the required startup capital to launch new ventures. Personal wealth may have dropped substantially through declining home values and home ownership rates. Recessions make it more difficult to acquire financing from banks, other financial institutions, angel investors, and venture capitalists.

On the other hand, the costs of production are lower in a recession, especially rent and labor, increasing $\mathrm{Y}^{\mathrm{SE}}$. The opportunity cost of capital, $r$, is likely to be lower in recessions also placing upward pressure on entrepreneurship. Certainly an important factor having a positive effect on the entrepreneurial decision is that compensation in the wage/salary sector decreases in economic contractions. The larger number of displaced and unemployed workers in an economic downturn increases necessity entrepreneurship. The positive effect of lower wages on 
entrepreneurship may be tempered somewhat in recessions, however, because some workers may be reluctant to leave their jobs in a recession due to concerns about finding another one if the business fails.

The net effect of these opposing forces on total business creation is ambiguous. This potentially explains why the previous studies find negative, positive and null relationship between entrepreneurship and the business cycle (Parker 2009; Bell and Blanchflower 2011; Congregado et al. 2012; Parker et al. 2012; Koellinger and Thurik 2012; Fairlie 2013). ${ }^{4}$ The net effects on opportunity and necessity entrepreneurship are less ambiguous. ${ }^{5}$ We expect to find that the number of new opportunity entrepreneurs relative to new necessity entrepreneurs is higher in economic growth periods and lower in recessions.

\section{Operationalizing the Distinction between Necessity and Opportunity Entrepreneurship}

To distinguish between opportunity versus necessity entrepreneurs, we use initial unemployment status. Individuals who are initially registered as unemployed before starting businesses are defined as being necessity entrepreneurs, because someone who registers as unemployed is, by definition, looking for employment. In contrast, individuals who are wage/salary workers, enrolled in school or college, or are not actively seeking a job before starting businesses are defined as being opportunity entrepreneurs. If business creation occurs out of these three prior labor market states then we view it as an "opportunity."

\footnotetext{
${ }^{4}$ This ambiguity could also explain differences in patterns across demographic groups. For example, Dávila and Mora (2013) find that self-employment increases during years of economic growth for Hispanics, but not for non-Hispanic whites.

${ }^{5}$ Opportunity entrepreneurship might be less strongly associated with the business cycle, because ideas for entrepreneurship might come stochastically, or at least relatively constantly, even if the resources and demand needed for implementation might not.
} 
This operationalization has several advantages. First, the classification criterion is objective and unambiguous. Every entrepreneur can be classified if the employment status before starting the business is known. Second, the data requirements are relatively light, so the approach can be applied to a broad set of available databases. In contrast, an approach that requires asking for specific motives to become an entrepreneur, for example, rules out the use of many available databases and in many cases requires the costly implementation of new and specific surveys, which often implies making compromises on sample size and representativeness. ${ }^{6}$

Panel data with at least two time-series observations almost automatically fulfills the requirements for our classification approach, but some limitations should be considered. A new entrant into entrepreneurship, who is an entrepreneur in period $t$, but not in period $t-1$, is labeled a necessity entrepreneur in $t$ and the subsequent periods while remaining an entrepreneur if he or she was unemployed in $t-1$, and an opportunity entrepreneur otherwise. This works for all entrepreneurs except for those who are already entrepreneurs in the first period of observation in the panel. Some panel surveys such as the German Socio-economic Panel (SOEP) elicit the retrospective employment history in the first interview with a new respondent, which allows recovering the employment status before starting the current business and classification even in these cases. Asking the retrospective information may come at the cost of recall bias, however. But, asking about prior unemployment status is objective.

\footnotetext{
${ }^{6}$ A related approach used by Block and Sandner (2009) and Block and Wagner (2010) uses information on how the person who becomes an entrepreneur exited from the previous wage and salary job. Entrepreneurs are classified as necessity entrepreneurs if they were dismissed or the firm that employed them closed down. If they voluntarily quit their previous job, they are classified as opportunity entrepreneurs. A drawback of this approach is that many datasets do not provide this information, and even if they do, only those entrepreneurs who were observed as wage/salary employees before becoming an entrepreneur can be classified. In addition, the authors exclude those entrepreneurs from the sample whose former wage job was terminated because a limited time contract expired as well as those who lost their last wage/salary job more than two years ago because classification would be too ambiguous in these cases. The consequence of these restrictions is that less than one third of the self-employed can be classified into opportunity and necessity entrepreneurs using this approach based on the SOEP data.
} 
The classification approach using the employment status in two subsequent waves of panel data will be sufficiently accurate for most analyses if the period between two interviews is not too long (say, one year or less). The longer the period between two interviews, the higher the risk of multiple employment transitions between them, which are not captured using this method. For example, somebody may be a paid employee at the time of the interview in $t-1$, then become unemployed, and then become an entrepreneur before the interview in $t$. In this case, the information on temporary unemployment would be missed, and the entrepreneur would be classified as an opportunity entrepreneur instead of as a necessity entrepreneur. Some panel surveys elicit calendar style information for the time between two interviews. For example, in each of the annual interviews, the respondents may be asked for their employment states in each month between the last and the current interviews. This would prevent missing any intermediate employment spells. Other panel surveys include questions such as "Have you ever been unemployed within the previous year" or "How many months did you receive unemployment benefits in the previous year", this would also be sufficient for our classification purpose.

Not only panel data, but also many cross-sectional databases enable our classification approach if they include a retrospective question. Some cross-sectional surveys not only ask for the current employment status, but also the previous one before the current employment spell. For example, surveys of business owners often ask whether the respondent was unemployed just prior to starting the business, which is sufficient for our classification. However, recall bias might be an important limitation, especially if the business was started many years ago. A second limitation is that only surviving businesses at the time of the interview are included in the analysis. This potentially implies survival bias, a common limitation to cross-sectional analyses. Other crosssectional questionnaires such as the German Micro Census ask for the current employment status 
as well as the employment status 12 months (or some other fixed period) ago. This allows classification of all new entrants into entrepreneurship into necessity and opportunity entrepreneurs, while those who were already entrepreneurs 12 months ago cannot be classified. This is sufficient for analyses that focus on entry into entrepreneurship. For many research questions, the dynamics of entrepreneurship are of more interest than the stock of entrepreneurs, especially if the intention is causal inference. However, if the retrospective question refers to a longer time ago, the same limitations occur as discussed before, namely recall bias and the danger of missing intermediate, multiple transitions between employment states.

Not only survey data, but also administrative data often include information allowing our classification approach, as long as minimal information on the employment history is included or can be reconstructed.

\section{Datasets}

To illustrate patterns in opportunity and necessity entrepreneurship based on these definitions, we use data from three nationally-representative and widely used sources of data - the matched U.S. Current Population Survey (CPS), the German Micro Census, and the German Socio-Economic Panel (SOEP). With more than 1 million observations per year, the matched CPS is one of the largest household survey panel datasets in the world. ${ }^{7}$ The CPS is used to estimate the widely reported and analyzed national unemployment rate in the monthly "Jobs Report" produced by the U.S. Bureau of Labor Statistics. The German Micro Census is an official annual

\footnotetext{
${ }^{7}$ The underlying datasets that are used to create the matched longitudinal data are the basic monthly files to the Current Population Survey (CPS). Households in the CPS are interviewed each month over a 4-month period. Eight months later they are re-interviewed in each month of a second 4-month period. Thus, individuals who are interviewed in January, February, March and April of one year are interviewed again in January, February, March and April of the following year. The rotation pattern of the CPS, thus allows for matching information on individuals monthly for 75 percent of all respondents to each survey because the fourth month in the rotation cannot be matched to a subsequent month. We focus on two-month matches across subsequent months. For more details on matching see Fairlie (2013).
} 
cross-sectional household survey provided by the German Federal Statistical Office. It consists of a $1 \%$ sample of the population in Germany, i.e. about 370,000 households per year. Most questions are subject to compulsory response, which ensures a low rate of non-response and that entrepreneurs are adequately represented. For additional analyses, we also use the SOEP, an annual household panel survey, which is provided by the German Institute for Economic Research, and which is similar to the U.S. Panel Study of Income Dynamics (PSID). It offers a very rich set of socio-demographic variables, but with about 22,000 individuals in 12,000 households, it covers a smaller sample size in comparison to the Micro Census. To add regional data such as the local unemployment rate, we merge local characteristics of Germany's 96 Spatial Planning Regions to our panel data. ${ }^{8}$

\section{Definition of Entrepreneurship in the CPS}

Using the matched CPS data over time, we create a measure of business formation that captures all new business owners including those who own incorporated or unincorporated businesses, and those who are employers or non-employers. To estimate the business formation rate in the matched CPS data, we first identify all individuals who do not own a business as their main job in the initial survey month in the two-month pair. By matching CPS files, we then identify whether they own a business as their main job with 15 or more usual weekly hours worked in the subsequent survey month. The entrepreneurship rate is thus defined as the percentage of the population of non-business owners that start a business each month. To identify whether individuals are business owners in each month we use information on their main job defined as the

\footnotetext{
${ }^{8}$ We obtain the regional data from the INKAR database provided by Germany's Federal Institute for Research on Building, Urban Affairs and Spatial Development (http://www.inkar.de/). Spatial Planning Regions in Germany are used for statistical reporting and do not have administrative functions on their own.
} 
one with the most hours worked. Thus, individuals who start side businesses will not be counted if they are working more hours on a wage and salary job. The 15 or more hours per week (or roughly 2 or more days per week) criterion is chosen to guarantee a reasonable work commitment to the new business.

\section{Definition of Entrepreneurship in the German Micro Census and SOEP}

In the German Micro Census and SOEP, we define entrepreneurship analogously to our definition using the CPS (i.e., we define those as entrepreneurs who report that self-employment is their main job and working 15 or more hours a week). Again this definition includes employers and non-employers. In both German data bases, we can identify business formation. Although the German Micro Census is cross-sectional, it not only asks for the current employment state, but also includes a retrospective question on a respondent's employment state in the year prior to the survey. This allows us to identify new necessity entrepreneurs, who were unemployed in $t$ - 1 and entrepreneurs in $t$, and new opportunity entrepreneurs, who were in another labor market state in t-1 and entrepreneurs in $t$. The main advantage of the Micro Census is its large sample size and representativeness, which makes it possible to analyze time trends with high precision.

The main advantages of the SOEP are the availability of a rich set of socio-demographic variables and its panel structure (see Wagner et al. 2007). When using the SOEP, we exploit the panel structure and identify new necessity (opportunity) entrepreneurs as those who are observed in unemployment (all other labor market states, respectively) in year $t-1$ and entrepreneurs in year $t$. We thus do not need to rely on retrospective information for determining opportunity and necessity entrepreneurship. 


\section{Previous Definitions}

To be sure, the idea of distinguishing between business creation out of unemployment and other labor force states is not new. Evans and Leighton (1989) was one of the first studies to document the high rate of self-employment coming out of unemployment. Farber (1999) also showed high rates of self-employment among displaced workers. Other studies have shown that prior unemployment is important for understanding the importance of liquidity constraints and risk attitude for entrepreneurship and measuring the effects of human capital on earnings and success of entrepreneurs (see, for a few examples, Fairlie and Krashinsky 2012; Caliendo et al. 2009; Fossen and Buettner 2013; Baptista et al. 2014).

As noted above, an early attempt at creating a working definition of opportunity vs. necessity entrepreneurship was provided by the Global Entrepreneurship Monitor (GEM). ${ }^{9}$ GEM uses responses to the following question: "Are you involved in this start-up to take advantage of a business opportunity or because you have no better choices for work?" The GEM has been widely used in the entrepreneurship literature; Bosma (2013) provides an overview of GEM-based academic publications. ${ }^{10}$ Other surveys adopted the same question to distinguish between opportunity and necessity entrepreneurship from the GEM. For example, the definition has been used in an online survey in Germany (Block and Koellinger 2009), a survey of recently established Finnish micro enterprises (Kautonen and Palmroos 2010), and the Flash Eurobarometer Survey on Entrepreneurship (Van der Zwang et al. 2016).

\footnotetext{
${ }^{9}$ See Reynolds et al. $(2001,2005)$ for a description and discussion of the survey.

${ }^{10}$ For examples of studies using the GEM and its definition of opportunity versus necessity entrepreneurship see Wennekers et al. (2005), Bergmann and Sternberg (2007), Ho and Wong (2007), Van Stel et al. (2007), Acs and Amorós (2008), Bjørnskov and Foss (2008), McMullen et al. (2008), Koellinger and Minniti (2009), Stephen et al. (2009), Stephan and Uhlaner (2010), Terjesen and Amorós (2010), Pinillos and Reyes (2011), Serida and Morales (2011), and Nissan et al. (2012).
} 
However, we are concerned about this distinction between opportunity and necessity entrepreneurship for several reasons. The primary concern is that this information is available only in a handful of existing datasets. Second, the GEM-type survey question is subjective. How one person interprets this question could be different than how another person interprets the question. Another concern is that the same person could differ in how they interpret the question over time (i.e. as they get older or at different parts of the business cycle). Fourth, entrepreneurs may base their responses to this question on how successful their business launch is going and not on prelaunch goals (although this is less of a concern for nascent entrepreneurship than actual business creation).

Another approach is to ask entrepreneurs for various motivational factors for their decision to become an entrepreneur. For example, the 2010 wave of the German SOEP asks those who newly became self-employed in the survey year how much they agree with eight statements, including "I have always wanted to be my own boss", "I had an idea that I really wanted to implement", "I did not want to be unemployed anymore", and "I did not find employment (anymore)." Similar approaches to distinguish between opportunity and necessity entrepreneurs are used, for example, in a sample of entrepreneurs in Belgium (Giacomin et al. 2011), the UK Quarterly Labour Force Survey (Dawson and Henley 2012), a sample of female entrepreneurs in Mexico (Calderon et al. 2017), and an alternative survey for Germany (Caliendo and Kritikos 2009, 2010).

To be sure, there exists some overlap between the previous unemployment distinction and motivation questions, but it far from perfect. Fossen and Buettner (2013) compare entrepreneurs who started their businesses out of unemployment with those who started out of employment with respect to the motivations they indicate in the 2010 wave of the SOEP. The authors find that for 
those who were initially employed, the wish to be their own boss is more important, while for those who were initially unemployed, escaping unemployment and being unable to find employment are more important reasons for becoming entrepreneurs. Interestingly, Caliendo and Kritikos $(2009,2010)$ find that many formerly unemployed entrepreneurs simultaneously indicate pull as well as push motives, making it difficult to categorize them into necessity or opportunity entrepreneurs.

Although we do not claim that our approach of using prior unemployment status provides a perfect dichotomy between opportunity and necessity entrepreneurship, we are concerned about using statements on the motives for entrepreneurship to define opportunity and necessity entrepreneurship. In particular, this approach does not meet three of the requirements that we specify above. Information on startup motivations is not available in most large, nationally representative datasets. This approach also might have potential inconsistency across individuals and time, and motivations are asked after start-up and answers might depend on the ex-post success of the business. Our definition does not suffer from these weaknesses, but certainly is not perfect as some unemployed individuals might find great opportunities for starting businesses and some wage/salary workers might face barriers leading to necessity entrepreneurship.

\section{Business Cycle Patterns}

\subsection{National Trends}

In this section, we show how our definitions of overall entrepreneurship, opportunity entrepreneurship and necessity entrepreneurship track the business cycle. Figure 1 displays the total number of new entrepreneurs vs. the national unemployment rate from 1996 to 2015 using 
the CPS. ${ }^{11}$ The number of new entrepreneurs captures the adult (ages 20-64), non-business owner population that starts a business each month. ${ }^{12}$ We focus on the period starting in 1996 because it captures the start of the strong economic growth period of the 1990s reasonably well and because of data limitations in matching the CPS in immediately preceding years. The period from the beginning of 1996 to 2015 captures two downturns and three growth periods. The NBER officially dates the end of the strong economic growth period of the late 1990s as March 2001 and the subsequent contraction period as ending in November 2001. The next peak of the business cycle was December 2007 and the official end of the "Great Recession" was June 2009, although unemployment remained very high over the next few years.

The number of new entrepreneurs shows a somewhat counter-cyclical pattern generally moving with the national unemployment rate. Both entrepreneurship and unemployment were high in 1996 then declined steadily in the strong economic growth period of the late 1990s. Both measures increased in the early 2000s corresponding with the recession. In the mid-2000s both measures declined at first but only the unemployment rate continued to decline until the start of the recession in 2007 . The unemployment rate rose very rapidly over the next two years during the Great Recession. In the few years immediately following the Great Recession the number of new entrepreneurs and unemployment rate fell, but as the unemployment rate continued to fall the number of new entrepreneurs changed course and has been increasing since 2013.

Figure 2 displays the number of new entrepreneurs and real GDP growth rates. Entrepreneurship displays a relatively weak counter-cyclical pattern when using real GDP growth rates to track economic conditions. One problem is that real GDP growth rates fluctuate making it difficult to see a more continuous measure of business cycle conditions. But, these results generally

\footnotetext{
11 The unemployment rate is from the U.S. Bureau of Labor Statistics (BLS).

${ }^{12}$ Sampling weights provided in the CPS are used to scale up to population numbers.
} 
paint the same picture as those displayed in Figure 1 for the relationship between entrepreneurship and the national unemployment rate.

The examination of trends from the CPS indicates that entrepreneurship does not follow a strong cyclical trend which may be due to the opposing forces of opportunity and necessity entrepreneurship. To investigate this question we separately examine trends in opportunity and necessity entrepreneurship. Figures 3 and 4 display the number of new opportunity and necessity entrepreneurs over the business cycle, respectively. The number of new opportunity entrepreneurs shows somewhat of a cyclical pattern. The number of opportunity entrepreneurs rose in the late 1990s, in the mid-2000s, and in the past few years. It declined during the early 2000s and around the Great Recession. The number of new necessity entrepreneurs shows a strong counter-cyclical trend moving strongly with the unemployment rate, which is what is expected based on the definition.

To combine and simplify these patterns, Figure 5 displays the opportunity share of new entrepreneurs (defined as the number of new opportunity entrepreneurs as a share of the total number of new entrepreneurs). Over the past two decades, the share of new business creation from opportunity entrepreneurship increased when economic conditions were improving and decreased when economic conditions were worsening. The largest share of opportunity entrepreneurship occurred at the height of the "Roaring 90s," and the smallest share was in 2009 at the end of the Great Recession. The share of opportunity business creation also decreased in the recession of the early 2000s and increased in the following growth period in the mid-2000s. The opportunity share of new entrepreneurs is clearly pro-cyclical. ${ }^{13}$

\footnotetext{
${ }^{13}$ We find a similar pattern of clear pro-cyclicality in the opportunity share when we exclude new entrepreneurs who were initially not in the labor force.
} 
Figures 1-4 display the number of new entrepreneurs over the business cycle. The patterns do not change when we implicitly adjust for trends in population size by focusing on entrepreneurship rates (which capture the percentage of the adult, non-business owner population that starts a business each month). Figure 6 displays the entrepreneurship rate over the business cycle. As expected the patterns do not differ substantially from patterns for the number of new entrepreneurs. Appendix Figures 1 and 2 display trends for similar rate measures for opportunity and necessity entrepreneurship. These also follow similar time series patterns. Opportunity entrepreneurship displays a weak pro-cyclical pattern and necessity entrepreneurship follows a strong counter-cyclical pattern.

Returning to trends in the number of new entrepreneurs displayed in Figure 1, it is possible to explain changes over time. For example, from 2006 before the Great Recession to 2010 when the Great Recession ended the number of new entrepreneurs increased by 85,370 per month. Most of the increase in business creation from the start to end of the Great Recession came from necessity entrepreneurship. The number of new necessity entrepreneurs increased by 53,886 (63 percent). In contrast, the recent increase in the total number of new entrepreneurs of 103,990 from 2013 to 2015 was entirely driven by the increase in the number of opportunity entrepreneurs. Separating out opportunity and necessity entrepreneurship is clearly important for understanding the patterns of business creation over the business cycle.

\section{Trends in Germany}

We examine trends in Germany using the German Micro Census. Due to the annual nature of the data, we report new entrepreneurs per year for Germany. Figure 7 plots the total number of new entrepreneurs and the unemployment rate, which is obtained from Germany's Federal 
Employment Agency (2017). Similar to the United States, the number of new entrepreneurs exhibits a weak counter-cyclical pattern moving mostly with the unemployment rate. Figure 8 shows the relationship between entrepreneurship and the real GDP growth rate, which is provided by German Federal Statistical Office (2016). No clear pattern emerges due to the erratic nature of GDP growth. In Figure 9, we look at new opportunity entrepreneurs separately. Like the total number of new entrepreneurs, the number of new opportunity entrepreneurs moves somewhat with the unemployment rate. A very clear relationship becomes apparent between the number of new necessity entrepreneurs and the unemployment rate (Figure 10). As expected, and as seen in the United States, the two trends move together indicating that necessity entrepreneurship is countercyclical. In contrast, the opportunity share of new entrepreneurs is strongly cyclical (Figure 11). In 2003-2005, when unemployment is at its peak, the share of opportunity entrepreneurs out of all new entrepreneurs falls from $90 \%$ to $80 \%$ and rises back to $90 \%$ thereafter. Finally, when we plot new entrepreneurship rates instead of numbers, very similar patterns emerge (Figure 12 and Appendix Figures 3 and 4), which is in line with our earlier observation from the U.S. data. ${ }^{14}$

We also look at differences between former West and East Germany that persist after reunification in 1990. In particular, the regional economy is much weaker in the east. While the total new entrepreneurship rate is almost the same in both parts of the country, distinguishing between opportunity and necessity entrepreneurship reveals important differences in the expected direction. The new necessity entrepreneurship rate in the east is double the rate in the west $(0.20 \%$ versus $0.10 \%$ in our SOEP sample), whereas the opportunity entrepreneurship rate is lower in the east $(0.62 \%$ versus $0.74 \%)$. Thus, exclusively considering the total new entrepreneurship rate hides substantial differences between the two types of entrepreneurship.

\footnotetext{
${ }^{14}$ The results also remain similar when we exclude those initially not in the labor force from the sample.
} 


\section{Regression Results}

We next examine the relationship between entrepreneurship and the business cycle in a regression framework. The regressions allow us to control for trends in demographic factors, regional population shifts, and long-term trends that might be correlated with business cycle dynamics. We first examine entrepreneurship in the United States using the matched CPS from 1996-2015.

Table 1 reports estimates from linear probability regressions for the probability of total new entrepreneurship, new opportunity entrepreneurship, and new necessity entrepreneurship. ${ }^{15}$ The sample for all three models includes the adult, non-business owner population in the initial survey month of the two-month panel. Total entrepreneurship captures individuals starting a business in the second survey month. Specifications 1 and 2 report estimates for the regression of the total entrepreneurship on the national unemployment rate with and without controls, respectively. The entrepreneurship probability has a positive association with the national unemployment rate indicating a counter-cyclical pattern. Controlling for demographic, regional and long-term factors does not change the estimate of the association between entrepreneurship and the unemployment rate.

We also estimate regressions for the probability of new opportunity and necessity entrepreneurship. Specifications 3 and 4 report estimates for regressions for the probability of opportunity entrepreneurship, and Specifications 5 and 6 report estimates for regressions for the probability of necessity entrepreneurship. The probability of opportunity entrepreneurship is not strongly associated with the national unemployment rate. The point estimate is negative, as

\footnotetext{
${ }^{15}$ Marginal effects for probit and logit models are similar and not reported.
} 
expected, but it is not statistically significant. The necessity entrepreneurship probability, however, is positively associated with the national unemployment rate.

The regression estimates confirm the trends displayed in the figures. Necessity entrepreneurship is counter-cyclical whereas opportunity entrepreneurship is weakly pro-cyclical. Also, demographic, regional and long-term trends are not responsible for the relationships with the business cycle.

The results from analogous regressions using the German SOEP appear in Table 2. Using annual panel data and the sample of adult non-entrepreneurs, the dependent variable is 1 if an individual reports entrepreneurship in the subsequent year. Those who are unemployed before the transition are classified as necessity entrepreneurs and all other new entrepreneurs are classified as opportunity entrepreneurs. Like in the United States, the national unemployment rate is positively associated with the total new entrepreneurship rate. This is statistically significant only when including control variables. There is no significant association of the unemployment rate with opportunity entrepreneurship. In contrast, new necessity entrepreneurship is positively and significantly related to the unemployment rate. Thus, in Germany like in the United States, the counter-cyclical movement of necessity entrepreneurship drives the counter-cyclicality of the total entrepreneurship rate.

\subsection{Local Economic Conditions}

We turn to examining the relationship between opportunity and necessity entrepreneurship and local economic conditions. In this case, we focus on metropolitan areas which capture local labor markets. Figure 13 displays average new total, opportunity and necessity entrepreneurship rates across several ranges of local unemployment rates. Variation across local labor markets and 
over time are used to generate the relationships displayed in the figure. There is a positive relationship between total new entrepreneurship rates and local unemployment rates. The distinction between opportunity and necessity entrepreneurship shows that this is driven by the even stronger association of necessity entrepreneurship with local unemployment rates. Necessity entrepreneurship rates increase substantially and monotonically from the lowest local unemployment rates to the highest local unemployment rates. In contrast to the clear results for necessity entrepreneurship we do not find a clear relationship between opportunity entrepreneurship and local unemployment rates.

Figure 14 displays the opportunity share of entrepreneurship across local unemployment rates. The relationship between the opportunity share of entrepreneurship and local unemployment rates is strongly negative. Higher local unemployment rates are associated with lower opportunity shares, consistent with the patterns found for opportunity and necessity entrepreneurship.

\section{Regression Results}

We also estimate regression models that replace the national unemployment rate with the MSA unemployment rate. ${ }^{16}$ Table 3 reports estimates from linear probability regressions for the probability of total new entrepreneurship, new opportunity entrepreneurship, and new necessity entrepreneurship including the local unemployment rate. The regressions control for demographic trends and differences across metropolitan areas that might confound the estimated relationship between entrepreneurship and local unemployment rates. Regional and urbanicity trends and differences, and long-term macro trends are also controlled for in the regressions.

\footnotetext{
${ }^{16}$ Observations from rural areas or not-identified MSAs are not included in the sample. These observations represent less than 25 percent of the total sample.
} 
Total entrepreneurship has a positive association with local unemployment rates. Necessity entrepreneurship, as expected also has a positive association with local unemployment rates. On the other hand, we do not find evidence of a negative association with opportunity entrepreneurship. These results generally confirm the patterns displayed in the figures and are consistent with the findings using the national unemployment rate as the measure of business cycle conditions.

\section{Results for Germany}

New entrepreneurship patterns by local unemployment rates in Germany are similar to those in the United States. In particular, the new necessity entrepreneurship rate generally increases with the local unemployment rate (Figure 15) whereas the opportunity share decreases (Figure 16). There is no clear trend in the total new entrepreneurship rate, however, which highlights again that this statistic alone disguises the important difference between the two types.

Table 4 shows linear probability regressions for Germany based on the SOEP. The main regressor of interest is the local unemployment rate in one of the 96 Spatial Planning Regions of Germany. The association between total new entrepreneurship and the local unemployment rate is positive, indicating counter-cyclicality, similar to the United States. The association between opportunity entrepreneurship and the unemployment rate is negative, indicating pro-cyclicality. However, the point estimates for total and opportunity entrepreneurship are not statistically significant. In contrast, necessity entrepreneurship is positively associated with the unemployment rate and statistically significant. This result confirms the counter-cyclical pattern of necessity entrepreneurship. 


\section{Business Types Associated with Opportunity vs. Necessity Entrepreneurship}

Do our definitions of opportunity and necessity entrepreneurship line up well with the creation of more growth-oriented businesses? We explore this question next. Table 5 reports estimates for several measures of the businesses created by new opportunity and necessity entrepreneurs based on the CPS. We find that new opportunity entrepreneurs are more likely to create incorporated businesses and are more likely to create employer businesses. ${ }^{17}$ These two factors are especially associated with the seriousness of the business venture (e.g., Astebro and Tag, 2015).

Incorporation status might represent another method of distinguishing between opportunity and necessity entrepreneurship. We explore this possibility by plotting trends in the incorporation share of new entrepreneurs vs. the unemployment rate using the CPS (Figure 17). One pattern that is extremely clear is that incorporation status has been steadily increasing in the United States over the past two decades. The share of new entrepreneurs starting incorporated businesses increased from 28 percent in 1996 to 36 percent in 2015. The incorporation share increased steadily from 1996 to 2008. It decreased slightly in the Great Recession, but did not decrease during the recession in the early 2000s. The dominant trend in the incorporation share of new entrepreneurs is a longterm upward trend and not one that closely follows the business cycle. A perhaps more important concern, however, is that incorporation status can be thought of as an ex-post business outcome. It might depend on the early success of the business venture. An important criterion in distinguishing between opportunity and necessity entrepreneurship noted above is that it is predetermined. But, incorporation status is defined simultaneously with the business creation decision.

\footnotetext{
${ }^{17}$ Employer status of business owners is only available in the CPS starting in 2014.
} 
Table 5 also reports the industry distributions for businesses created by new opportunity and necessity entrepreneurs. Opportunity entrepreneurs are more likely to start businesses than necessity entrepreneurs in agriculture, wholesale/retail trade, and education/health. Necessity entrepreneurs are more likely to start businesses in construction. These differences generally line up with opportunity entrepreneurs starting businesses in industries with higher barriers to entry. But, overall we find that both opportunity and necessity entrepreneurs are fairly spread across industries.

Using the SOEP, we find that opportunity entrepreneurship is related to indicators of growth-oriented businesses in Germany as well (Table 6). New opportunity entrepreneurs are more likely to hire workers: Three quarters of new necessity entrepreneurs are solo-entrepreneurs, but only $53 \%$ of new opportunity entrepreneurs. New opportunity entrepreneurs also earn substantially more per month than necessity entrepreneurs. The difference is even larger with regard to business assets. New necessity entrepreneurs are more likely to work in the construction industry in Germany, like in the United States, although the difference between opportunity and necessity entrepreneurs is not as large in this respect in Germany. Unfortunately, neither the SOEP nor the Micro Census provide information on incorporation status.

\section{Conclusions}

In this paper, we create an operational definition of necessity and opportunity entrepreneurship that satisfies four criteria: i) consistent with theory, ii) objectively defined, iii) empirically measurable ex-ante, and iv) available in many large, nationally representative datasets. Using panel data or retrospective information we define individuals who are initially unemployed before starting businesses as "necessity" entrepreneurs, and define individuals who are not 
unemployed (i.e. wage/salary workers, enrolled in school or college, or are not actively seeking a job) before starting businesses as "opportunity" entrepreneurs. We document that overall entrepreneurship is somewhat counter-cyclical, but once we distinguish between opportunity and necessity entrepreneurship associations with the business cycle become clearer. Opportunity entrepreneurship is generally pro-cyclical and necessity entrepreneurship is strongly countercyclical. Opportunity entrepreneurship is also found to be associated with more growth-oriented businesses.

To be sure, it is impossible to create a perfectly clean dichotomy along the lines of opportunity and necessity entrepreneurship. Entrepreneurship or business ownership is more broadly determined by both supply and demand factors. An outward shift in demand for the goods and services typically produced by entrepreneurs or an outward shift in the availability of capital could lead to more opportunity entrepreneurship, whereas an inward shift in demand for wage and salary jobs could lead to more necessity entrepreneurship. Economic fluctuations, however, are likely to affect all of these factors and not just one in isolation, thus making it difficult to cleanly dichotomize the underlying motivations for starting a business. Furthermore, not all businesses created from unemployment will be out of necessity as some unemployed workers might have good opportunities in the wage/salary sector, and similarly, not all businesses created from wage/salary work will be opportunity entrepreneurship as some wage/salary workers might be receiving low pay or facing reduced work hours. But, the dichotomy between opportunity and necessity entrepreneurship defined here could be valuable for future research on the determinants and outcomes of entrepreneurship. For example, research focusing on the determinants of more growth-oriented entrepreneurship (and not necessity entrepreneurship) might want to exclude the previously unemployed in some specifications. Although researchers need to be careful about the 
potential for removing some ultimately very successful business ventures this approach could tighten up estimates and provide clearer results.

\section{References}

Acs, Z.J., and J.E. Amorós (2008): Entrepreneurship and Competitiveness in Latin America. Small Business Economics 31(3), 305-322.

Angrist, J.D., and J.-S. Pischke (2009): Mostly Harmless Econometrics: An Empiricist's Companion. Princeton University Press.

Astebro, T.B., and J. Tag (2015): Entrepreneurs and Job Creation. IFN Working Paper 1059, http://ssrn.com/abstract=2576044.

Baptista, R., M. Karaöz, and J. Mendonça (2014): The Impact of Human Capital on the Early Success of Necessity versus Opportunity-based Entrepreneurs. Small Business Economics 42, 831-847.

Bell, D.N.F., and D.G. Blanchflower (2011): Underemployment in the UK in the Great Recession. National Institute Economic Review 215(1), R23-R33.

Bergmann, H., and R. Sternberg (2007): The Changing Face of Entrepreneurship in Germany. Small Business Economics 28(2-3), 205-221.

Bjørnskov, C., and N.J. Foss (2008): Economic Freedom and Entrepreneurial Activity: Some Cross-country Evidence. Public Choice 134(3-4), 307-328.

Block, J.H., C.O. Fisch, and M. Van Praag (2017): The Schumpeterian Entrepreneur: A Review of the Empirical Evidence on the Antecedents, Behaviour and Consequences of Innovative Entrepreneurship. Industry and Innovation 24(1), 61-95.

Block, J., and P. Koellinger (2009): I Can't Get No Satisfaction-Necessity Entrepreneurship and Procedural Utility. Kyklos 62(2), 191-209.

Block, J., and P. Sandner (2009): Necessity and Opportunity Entrepreneurs and Their Duration in Self-employment: Evidence from German Micro Data. Journal of Industry, Competition and Trade 9, 117-137.

Block, J., and M. Wagner (2010): Necessity and Opportunity Entrepreneurs in Germany: Characteristics and Earnings Differentials. Schmalenbach Business Review 62(2), 154-174.

Bosma, N. (2013): The Global Entrepreneurship Monitor (GEM) and Its Impact on Entrepreneurship Research. Foundations and Trends in Entrepreneurship 9(2), 143-248.

Calderon, G., L. Iacovone, and L. Juarez (2017): Opportunity versus Necessity: Understanding the Heterogeneity of Female Micro-Entrepreneurs. World Bank Economic Review 30(Suppl. 1), S86-S96.

Caliendo, M., F.M. Fossen, and A.S. Kritikos (2009): Risk Attitudes of Nascent EntrepreneursNew Evidence from an Experimentally Validated Survey. Small Business Economics 32, 153167.

Caliendo, M., and A.S. Kritikos (2009): "I Want to, But I also Need to": Start-Ups Resulting from Opportunity and Necessity. IZA Discussion Paper 4661.

Caliendo, M., and A.S. Kritikos (2010): Start-ups by the Unemployed: Characteristics, Survival and Direct Employment Effects. Small Business Economics 35, 71-92. 
Congregado, E., A.A. Golpe, and S.C. Parker (2012): The Dynamics of Entrepreneurship: Hysteresis, Business Cycles and Government Policy. Empirical Economics 43, 1239-1261.

Dawson, C., and A. Henley (2012): 'Push' Versus 'Pull' Entrepreneurship: An Ambiguous Distinction? International Journal of Entrepreneurial Behaviour \& Research 18(6), 697-71.

Dávila, A., and M. Mora (2013): Hispanic Entrepreneurs in the 2000s: An Economic Profile and Policy Implications. Stanford University Press.

Evans, D.S., and L.S. Leighton (1989): Some Empirical Aspects of Entrepreneurship. American Economic Review 79(3), 519-535.

Evans, D.S., and B. Jovanovic (1989): An Estimated Model of Entrepreneurial Choice under Liquidity Constraints. Journal of Political Economy 97(4), 808-827.

Fairlie, R.W. (2013): Entrepreneurship, Economic Conditions, and the Great Recession. Journal of Economics \& Management Strategy 22(2), 207-231.

Fairlie, R.W., and H.A. Krashinsky (2012): Liquidity Constraints, Household Wealth, and Entrepreneurship Revisited. Review of Income and Wealth 58(2), 279-306.

Farber, H.S. (1999): Alternative and Part-time Employment Arrangements as a Response to Job Loss. Journal of Labor Economics 17(4), Part 2, S142-S169.

Federal Employment Agency (2017): Arbeitsmarkt in Zahlen, Monats-/Jahreszahlen, $\begin{array}{llll}\text { Arbeitslosigkeit im } & \text { Zeitverlauf, } & \text { November }\end{array}$ https://statistik.arbeitsagentur.de/nn_217700/Statischer-Content/Rubriken/Arbeitslose-undgemeldetes-Stellenangebot/Arbeitslose/Arbeitslosigkeit-in-Deutschland-seit-1950-MonatsJahreszahlen.html (last accessed February 13, 2017).

Fossen, F.M., and T.J.M. Buettner (2013): The Returns to Education for Opportunity Entrepreneurs, Necessity Entrepreneurs, and Paid Employees. Economics of Education Review 37, 66-84.

Fritsch, M., A. Kritikos, and K. Pijnenburg (2015): Business Cycles, Unemployment and Entrepreneurial Entry-Evidence from Germany. International Entrepreneurship and Management Journal 11, 267-286.

German Federal Statistical Office (2016): Inlandsproduktsberechnung, Lange Reihen ab 1970. Fachserie 18 Reihe 1.5-2015.

Giacomin, O., F. Janssen, J.-L. Guyot, and O. Lohest (2011): Opportunity and/or Necessity Entrepreneurship? The Impact of the Socio-economic Characteristics of Entrepreneurs. MPRA (Munich Personal RePEc Archive) Working Paper 29506.

Ho, Y., and P. Wong (2007): Financing, Regulatory Costs and Entrepreneurial Propensity. Small Business Economics 28(2-3), 187-204.

Kautonen, T., and J. Palmroos (2010): The Impact of Necessity-based Start-up on Subsequent Entrepreneurial Satisfaction. International Entrepreneurship and Management Journal 6, 285300.

Koellinger, P., and M. Minniti (2009): Unemployment Benefits Crowd Out Nascent Entrepreneurial Activity. Economics Letters 103(2), 96-98.

Koellinger, P.D., and A.R. Thurik. (2012): Entrepreneurship and the Business Cycle. Review of Economics and Statistics 94(4), 1143-1156.

Nissan, E., M. Castano, and I. Carrasco (2012). Drivers of Non-profit Activity: A Cross-country Analysis. Small Business Economics 38(3), 303-320.

McMullen, J.S., R.D. Bagby, and L.E. Palich (2008): Economic Freedom and the Motivation to Engage in Entrepreneurial Action. Entrepreneurship: Theory and Practice 32(5), 875-895.

Parker, S.C. (2009): The Economics of Entrepreneurship. Cambridge University Press, UK. 
Parker, S.C., E. Congregado, and A.A. Golpe (2012): Is Entrepreneurship a Leading or Lagged Indicator of the Business Cycle? Evidence from UK Self-employment Data. International Small Business Journal 30(7), 736-753.

Pinillos, M., and L. Reyes (2011): Relationship Between Individualist-collectivist Culture and Entrepreneurial Activity: Evidence from Global Entrepreneurship Monitor Data. Small Business Economics 37(1), 23-37.

Reynolds, P.D., N. Bosma, E. Autio, S. Hunt, N. De Bono, I. Servais, P. Lopez-Garcia, and N. Chin (2005): Global Entrepreneurship Monitor: Data Collection Design and Implementation 1998-2003. Small Business Economics 24, 205-231.

Reynolds, P.D., S.M. Camp, W.D. Bygrave, E. Autio, and M. Hay. (2001): Global Entrepreneurship Monitor 2001 Executive Report. Babson College and London Business School.

Serida, J.N., and O.T. Morales (2011): Using the Theory of Planned Behavior to Predict Nascent Entrepreneurship. Academia, Revista Latinoamericana de Administración 46, 55-71.

Stephan, U., and L. Uhlaner (2010): Performance-based vs Socially Supportive Culture: A Crossnational Study of Descriptive Norms and Entrepreneurship. Journal of International Business Studies 41, 1347-1364.

Stephen, F., D. Urbano, and S. Van Hemmen (2009): The Responsiveness of Entrepreneurs to Working Time Regulations. Small Business Economics 32, 259-276.

Terjesen, S., and J.E. Amorós (2010): Female Entrepreneurship in Latin America and the Caribbean: Characteristics, Drivers and Relationship to Economics Development. European Journal of Development Research 22(3), 313-330.

Van der Zwang, P., R. Thurik, I. Verheul, and J. Hessels (2016): Factors Influencing the Entrepreneurial Engagement of Opportunity and Necessity Entrepreneurs. Eurasian Business Review 6, 273-295.

Van Stel, A., D.J. Storey, and A.R. Thurik (2007): The Effect of Business Regulation on Nascent and Young Business Entrepreneurship. Small Business Economics 28(2-3), 171-186.

Wagner, G.G., J.R. Frick, and J. Schupp (2007): The German Socio-economic Panel Study (SOEP): Scope, Evolution and Enhancements. Schmollers Jahrbuch-Journal of Applied Social Science Studies 127(1), 139-170.

Wennekers, S.A., A. van Stel, R. Thurik, and P. Reynolds (2005): Nascent Entrepreneurship and the Level of Economic Development. Small Business Economics 24(3), 293-309. 
Figure 1

Number of New Entrepreneurs and Unemployment Rates (1996-2015)

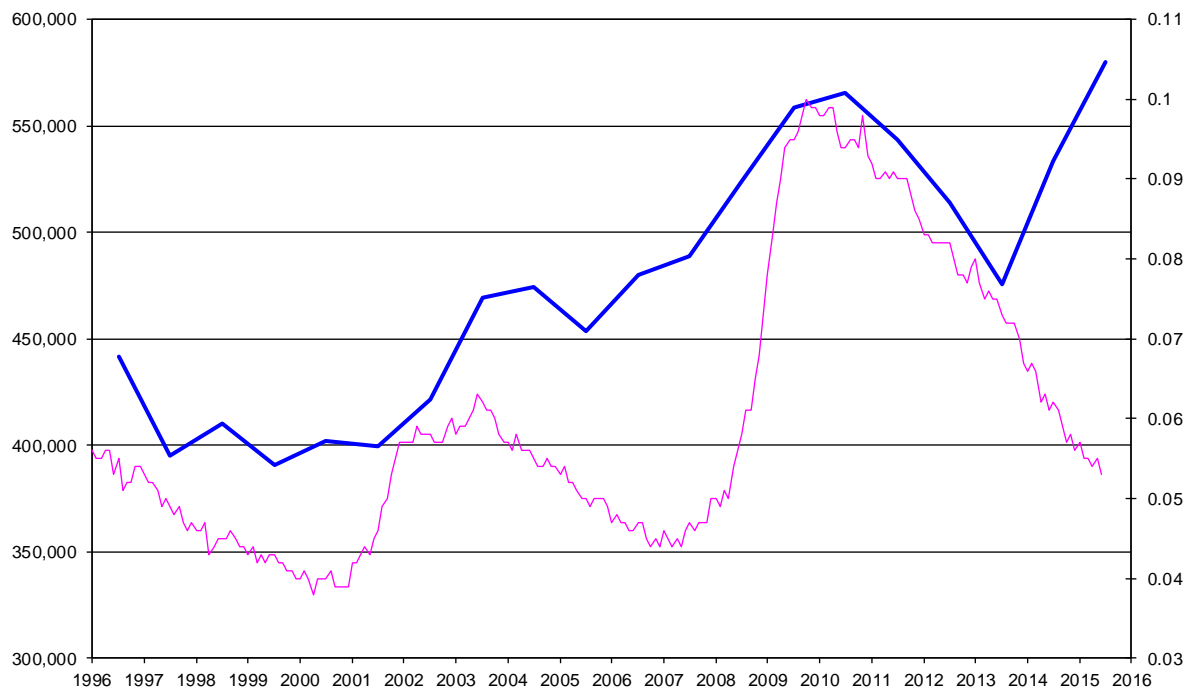

— Number of New Entrepreneurs" — Unemployment Rate

Figure 2

Number of New Entrepreneurs and Real GDP Growth Rates (1996-2015)

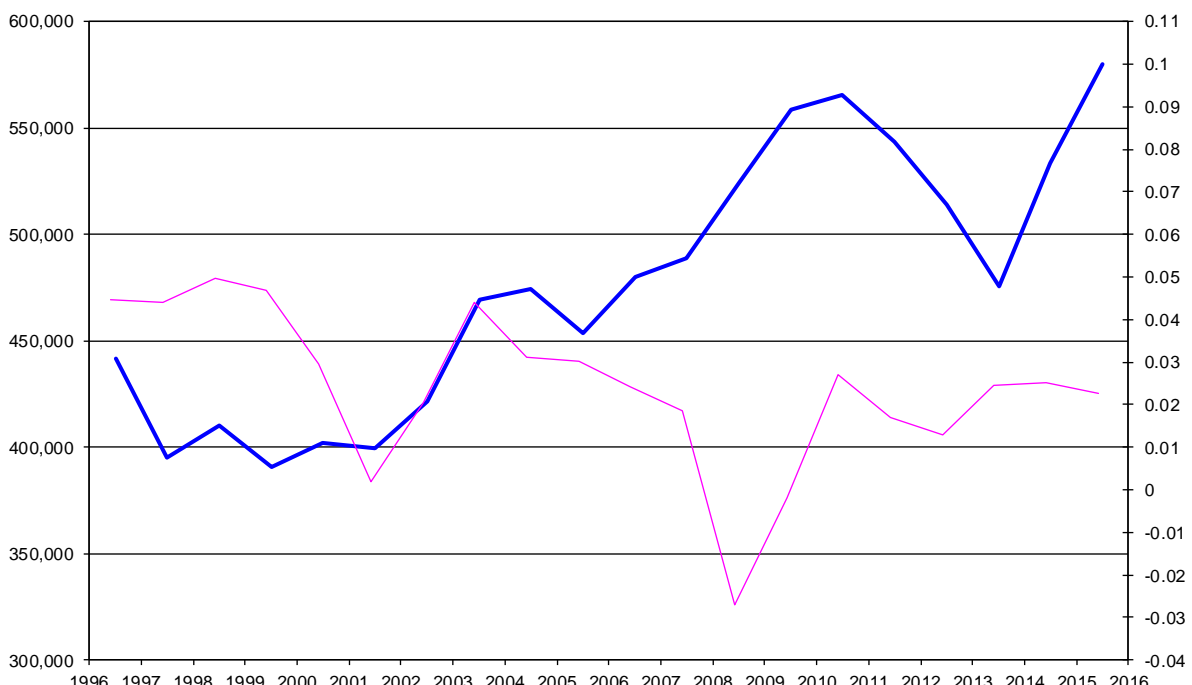

199619971998199920002001200220032004200520062007200820092010201120122013201420152016

—Number of New Entrepreneurs" — Real GDP Growth Rate 
Figure 3

Number of New Opportunity Entrepreneurs and Unemployment Rates (1996-2015)

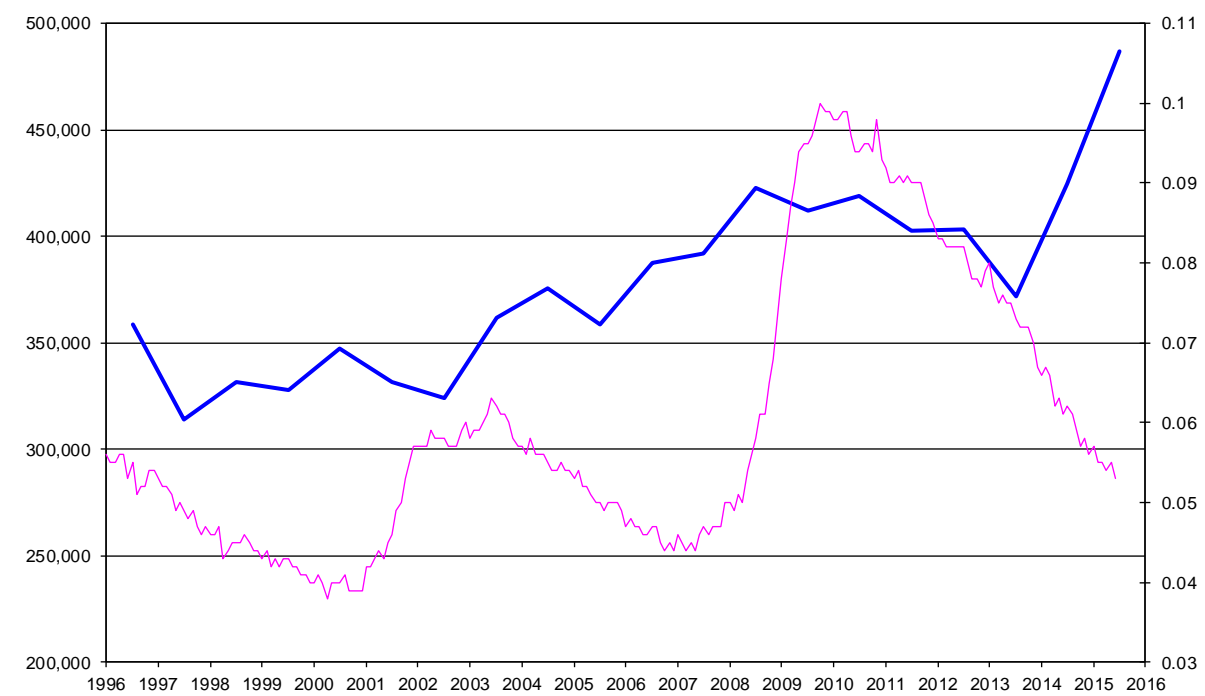

—Number of Opportunity Entrepreneurs" —unemployment Rate

Figure 4

Number of New Necessity Entrepreneurs and Unemployment Rates (1996-2015)

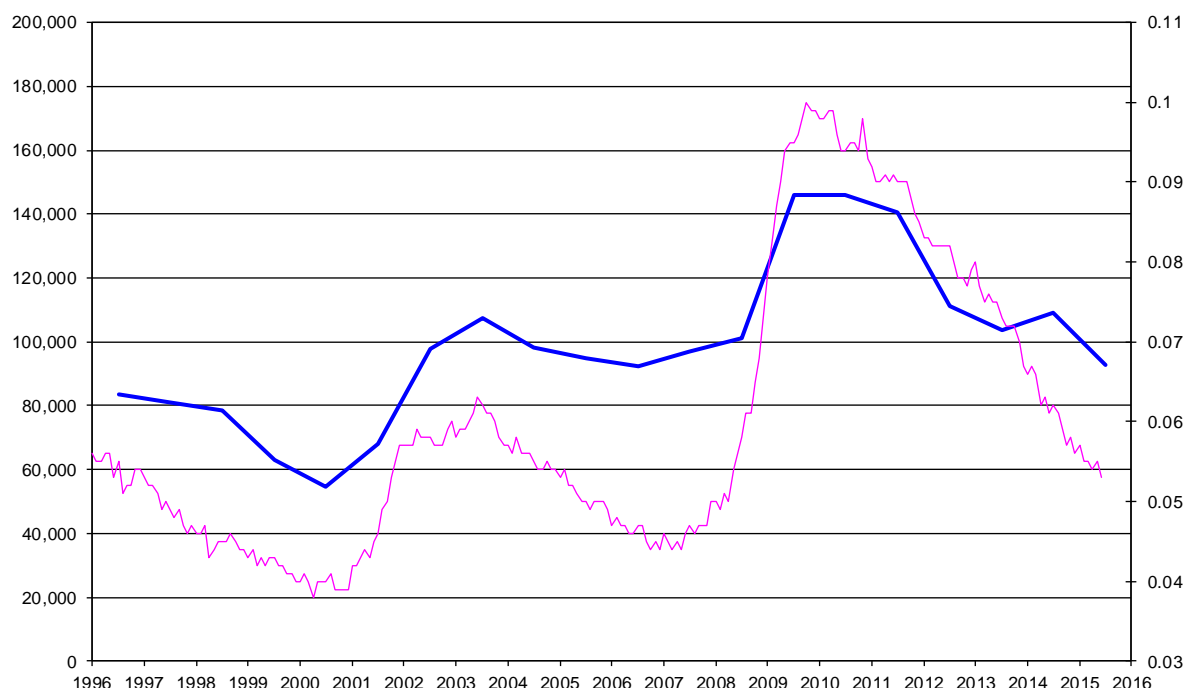

— Number of Necessity Entrepreneurs" _ Unemployment Rate 
Opportunity Share of New Entrepreneurs and Unemployment Rate (1996-2015)

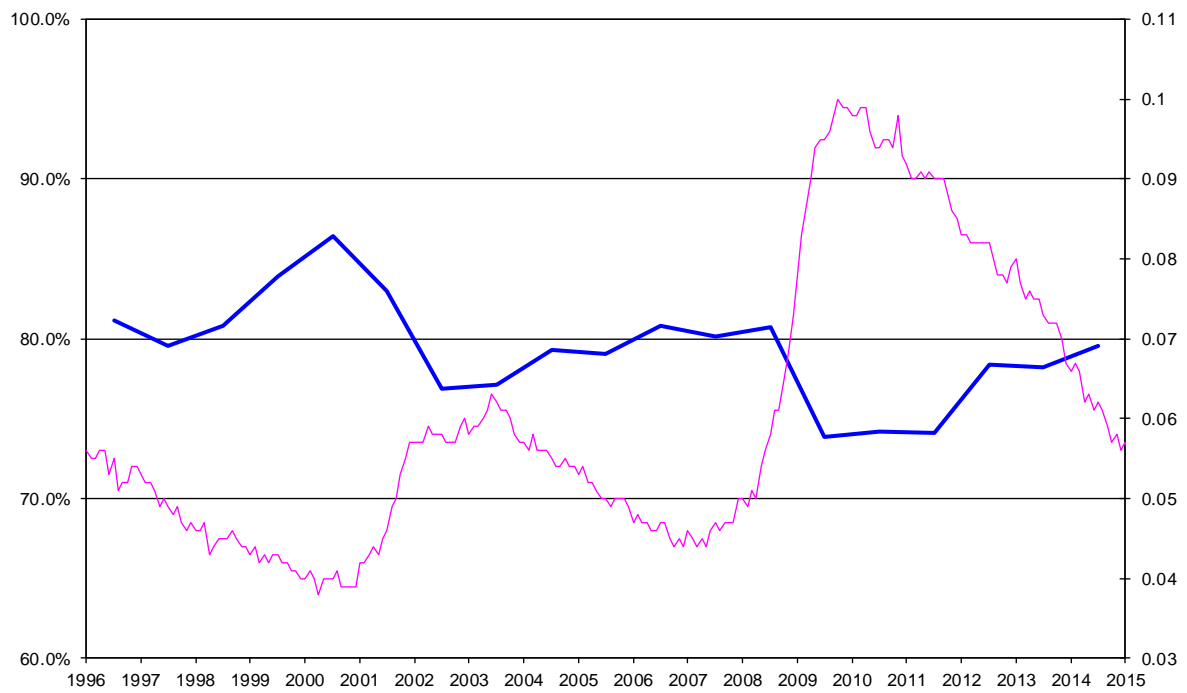

Figure 6

New Entrepreneurship Rate and Unemployment Rates (1996-2015)

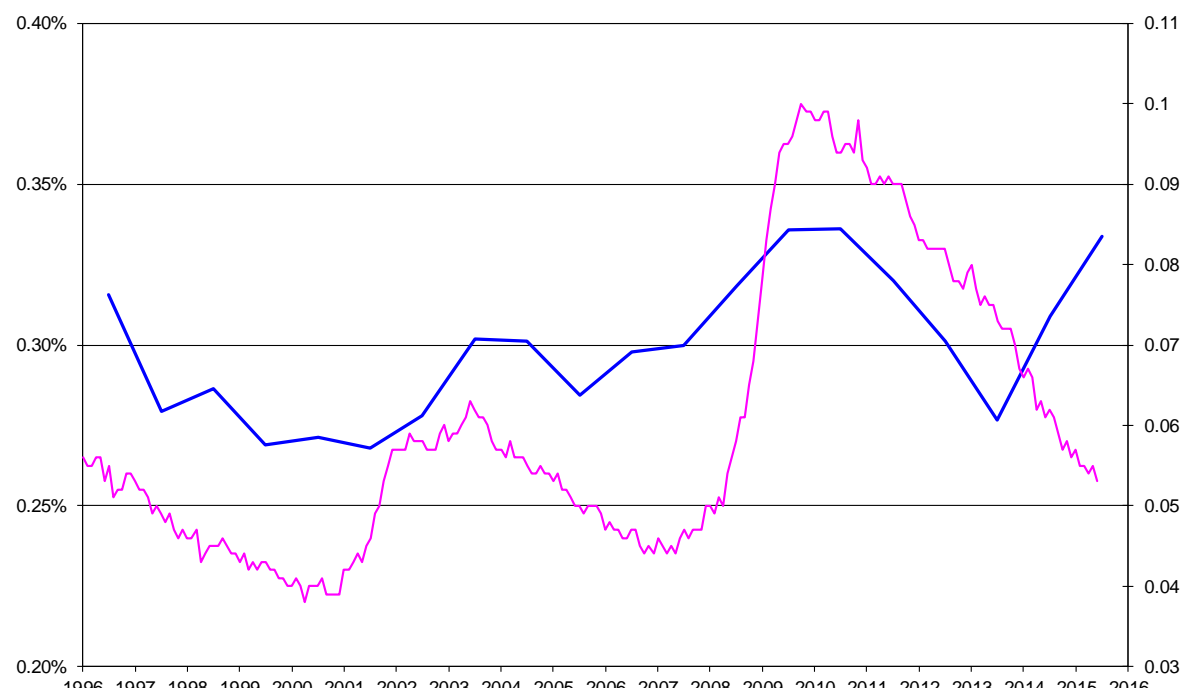

199619971998199920002001200220032004200520062007200820092010201120122013201420152016

-Entrepreneurship Rate —Unemployment Rate 
Figure 7

Number of New Entrepreneurs and Unemployment Rates in Germany (1996-2015)

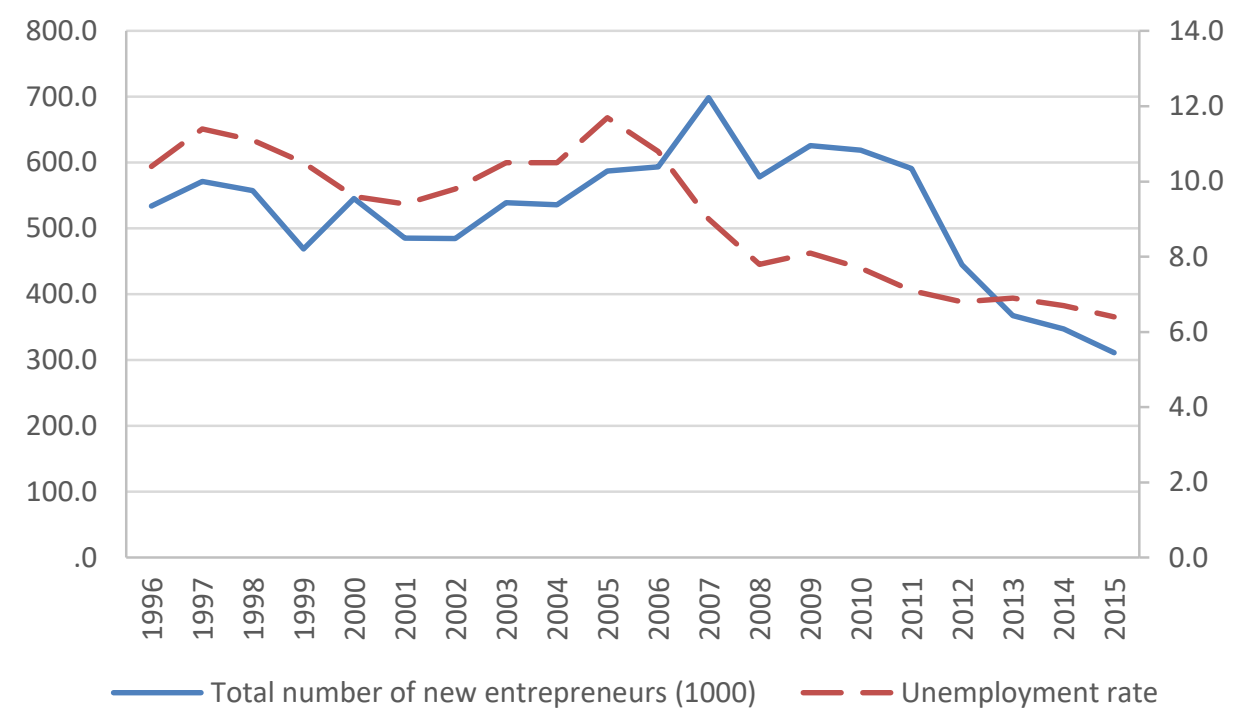

Figure 8

Number of New Entrepreneurs and Real GDP Growth Rates in Germany (1996-2015)

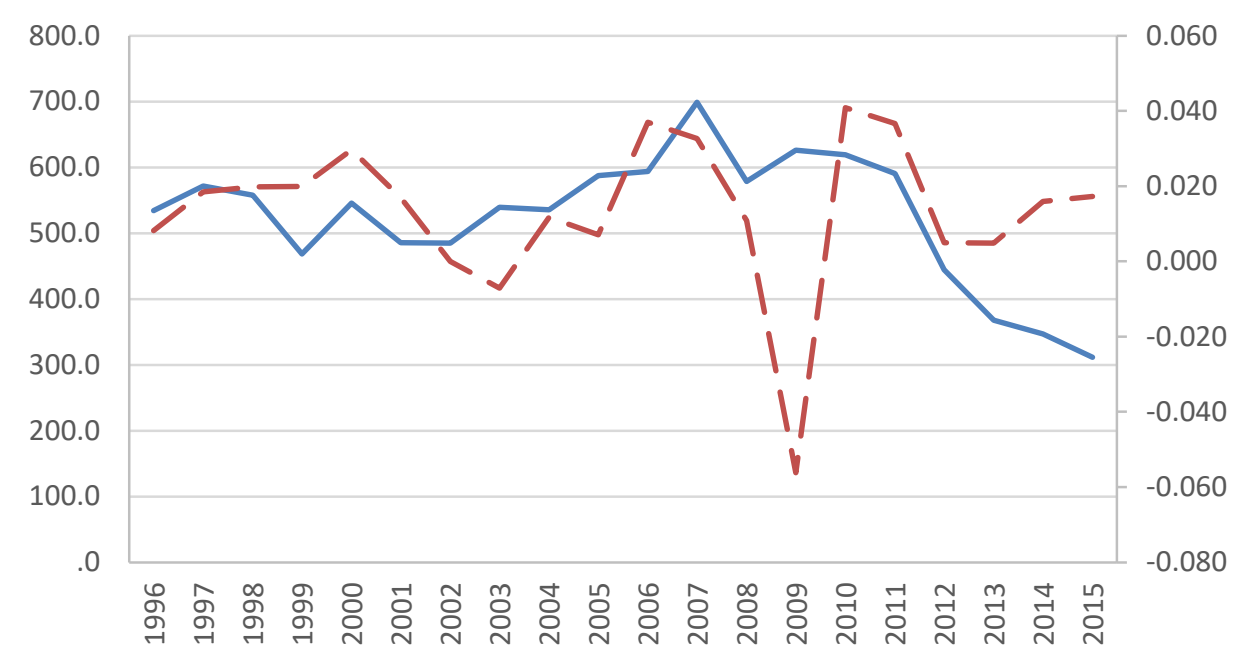

Total number of new entrepreneurs (1000) _ - Real GDP growth rate 
Figure 9

Number of New Opportunity Entrepreneurs and Unemployment Rates in Germany (1996-2015)

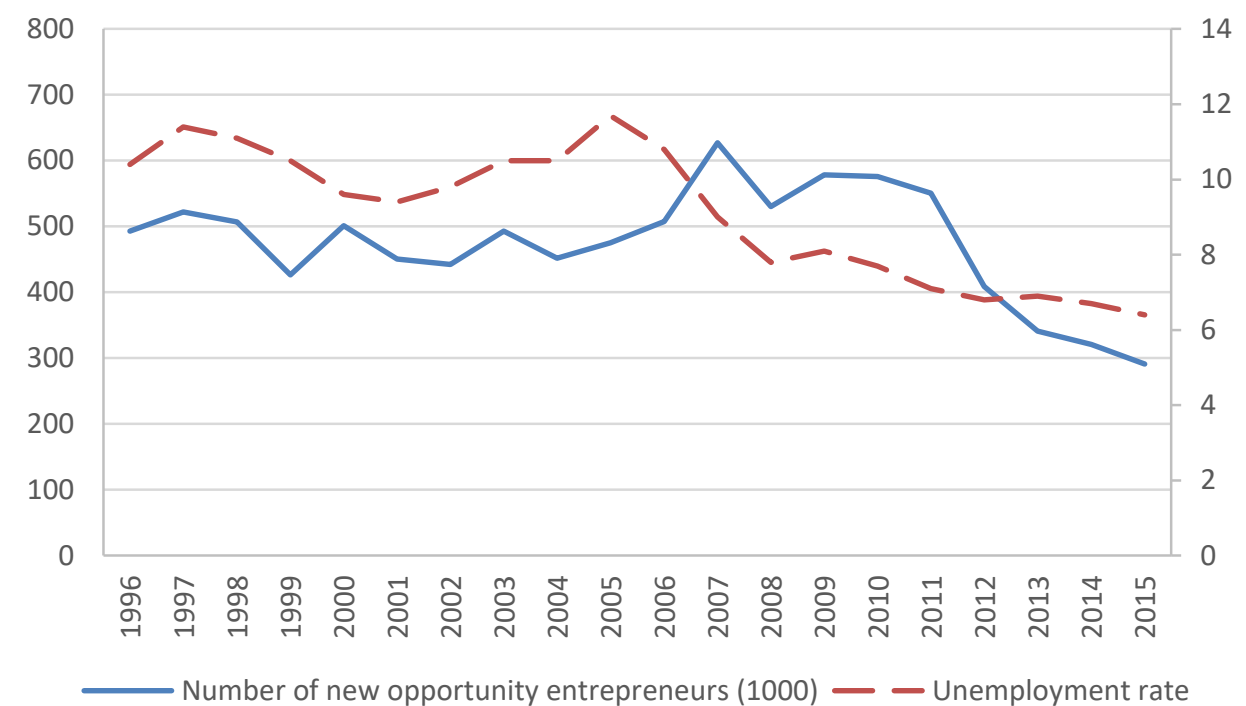

Figure 10

Number of New Necessity Entrepreneurs and Unemployment Rates in Germany (1996-2015)

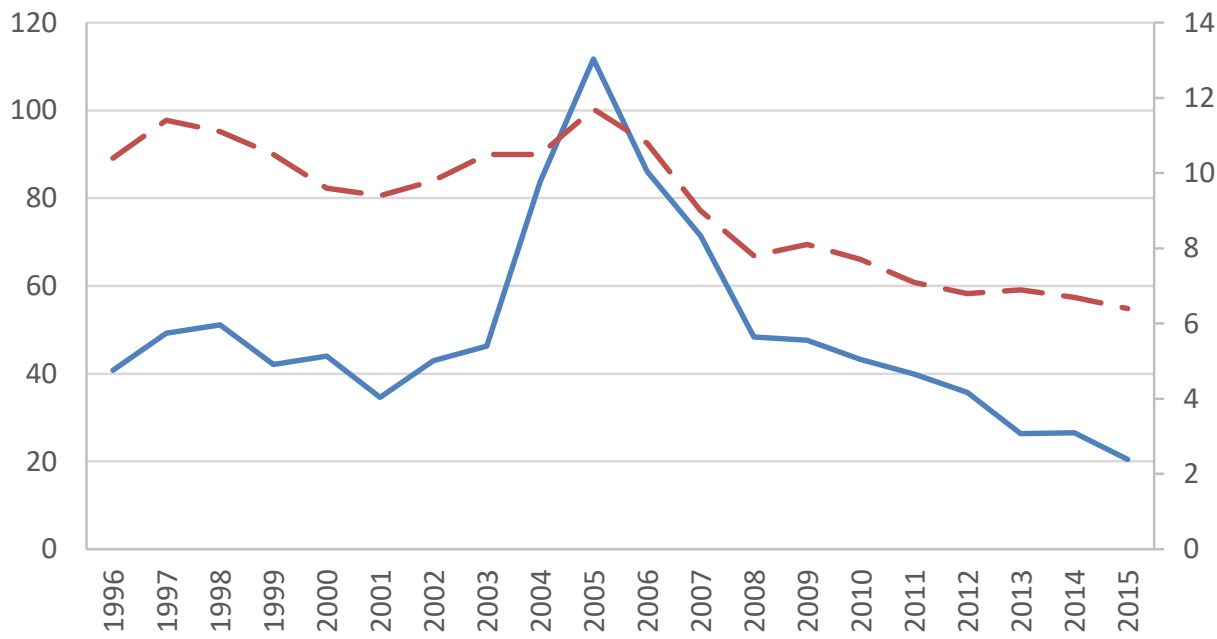

Number of new necessity entrepreneurs (1000) — Unemployment rate 
Figure 11

Opportunity Share of New Entrepreneurs and Unemployment Rates in Germany (1996-2015)

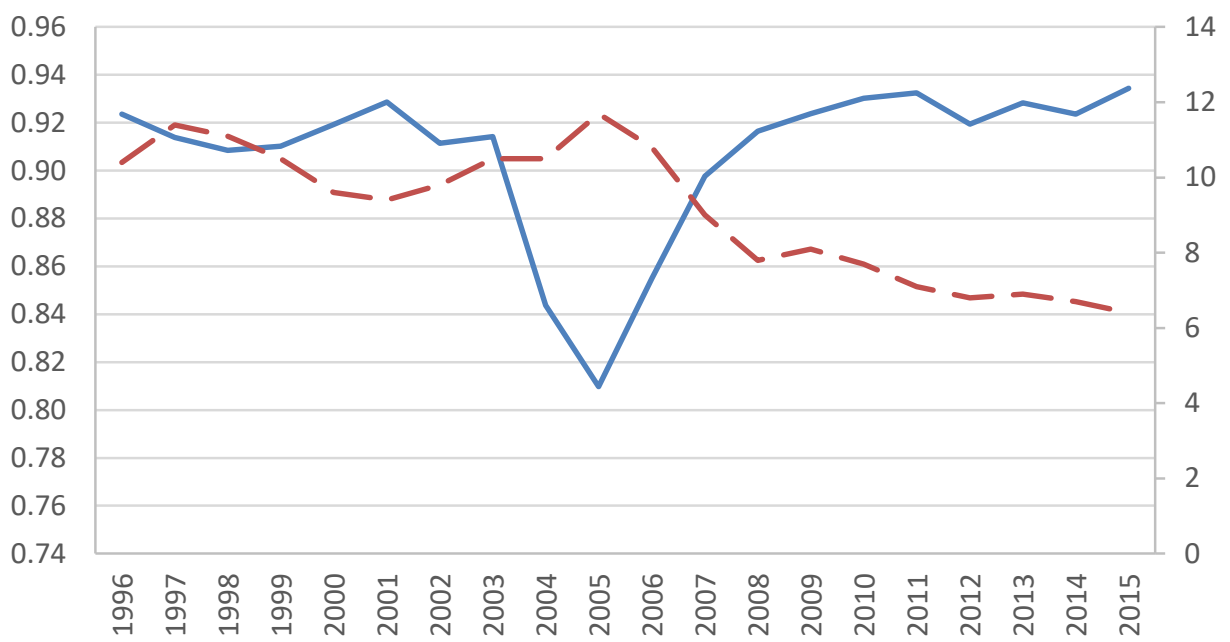

Opportunity share of new entrepreneurs _ - Unemployment rate

Figure 12

New Entrepreneurship Rate and Unemployment Rates in Germany (1996-2015)

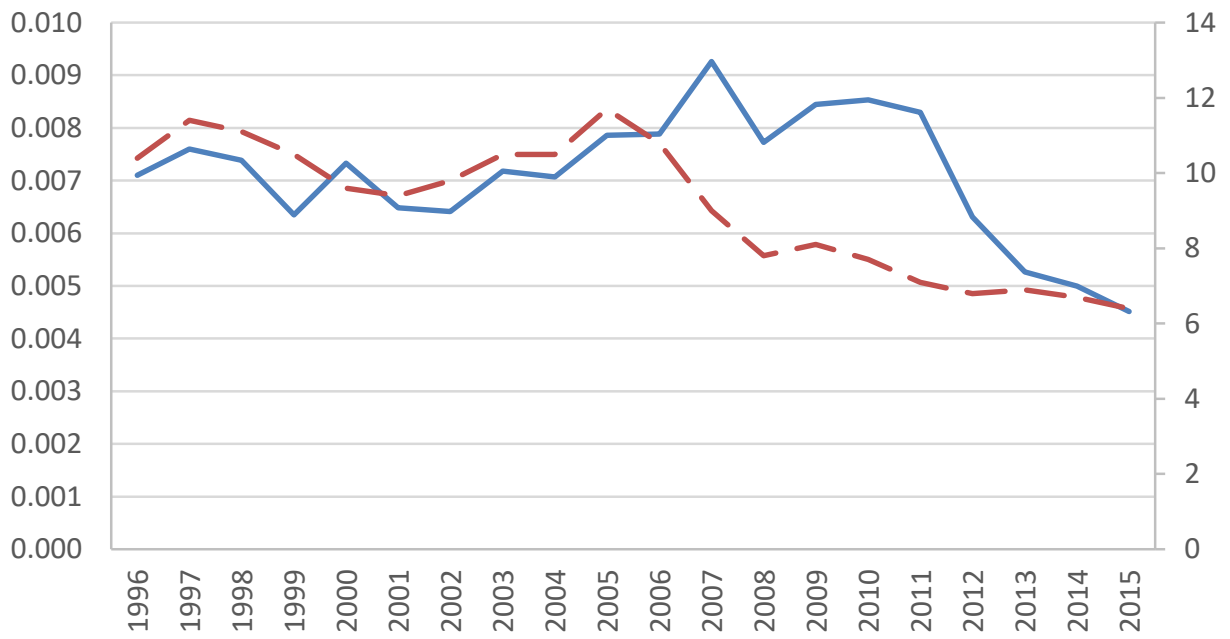

Total entrepreneurship rate $\quad-$ Unemployment rate 
Figure 13: New Entrepreneurship Rates by Local Unemployment Rates

Current Population Survey (1996-2016)

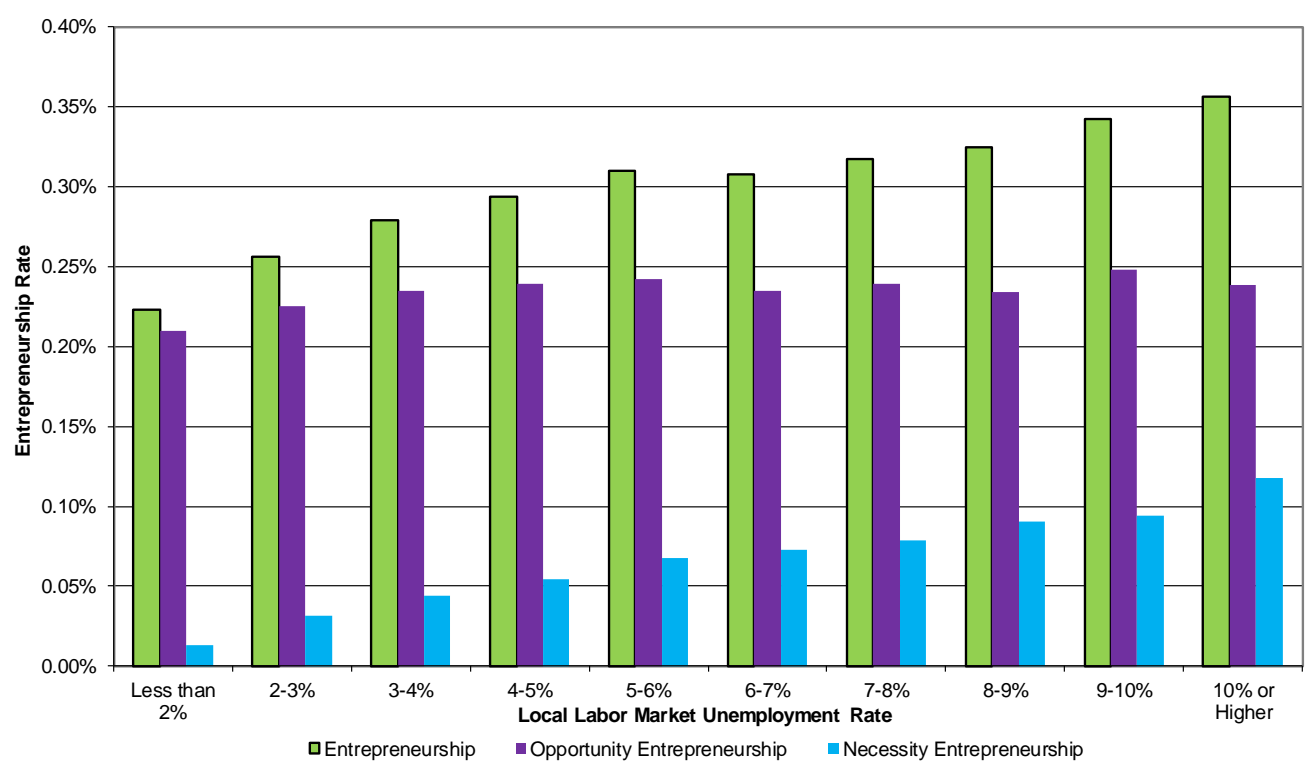

Figure 14: Opportunity Share of New Entrepreneurs by Local Unemployment Rates Current Population Survey (1996-2016)

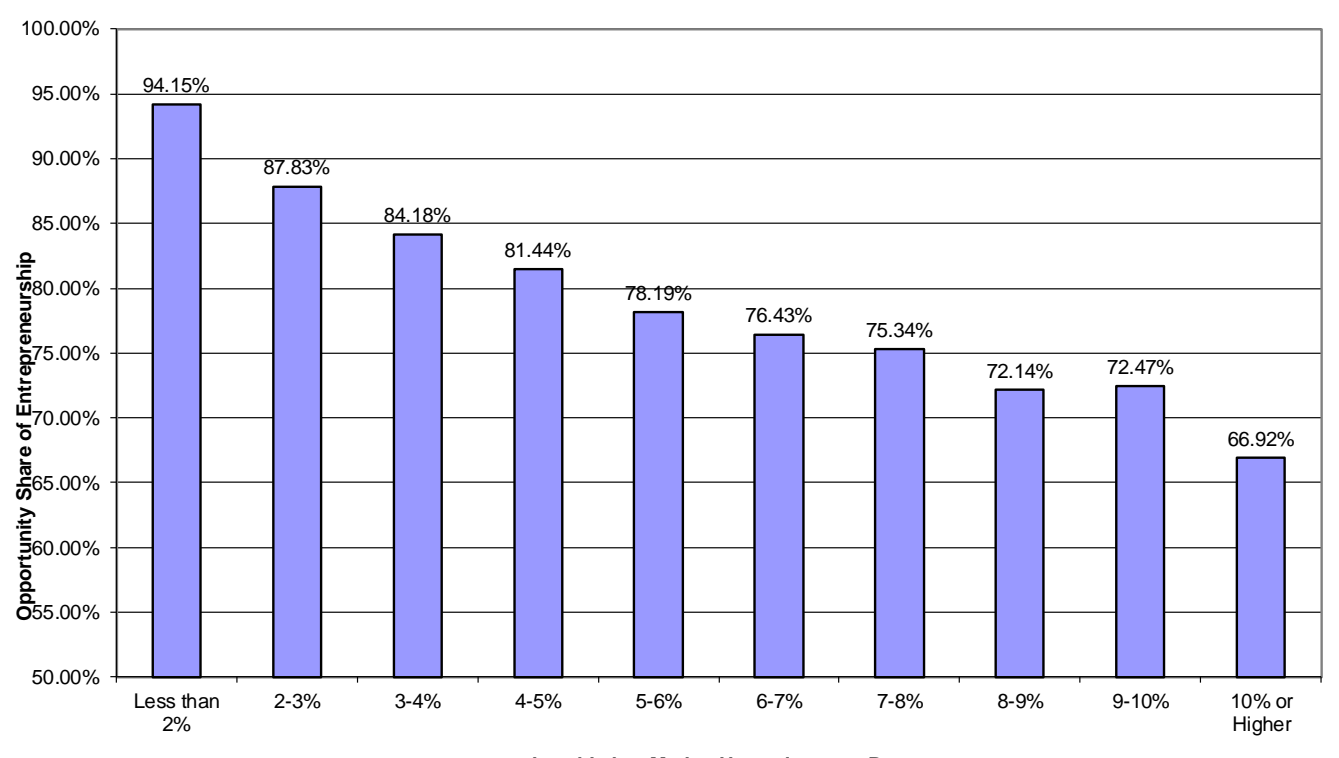

Local Labor Market Unemployment Rate 
Figure 15

New Entrepreneurship Rates by Local Unemployment Rates German Socio-economic Panel (1996-2015)

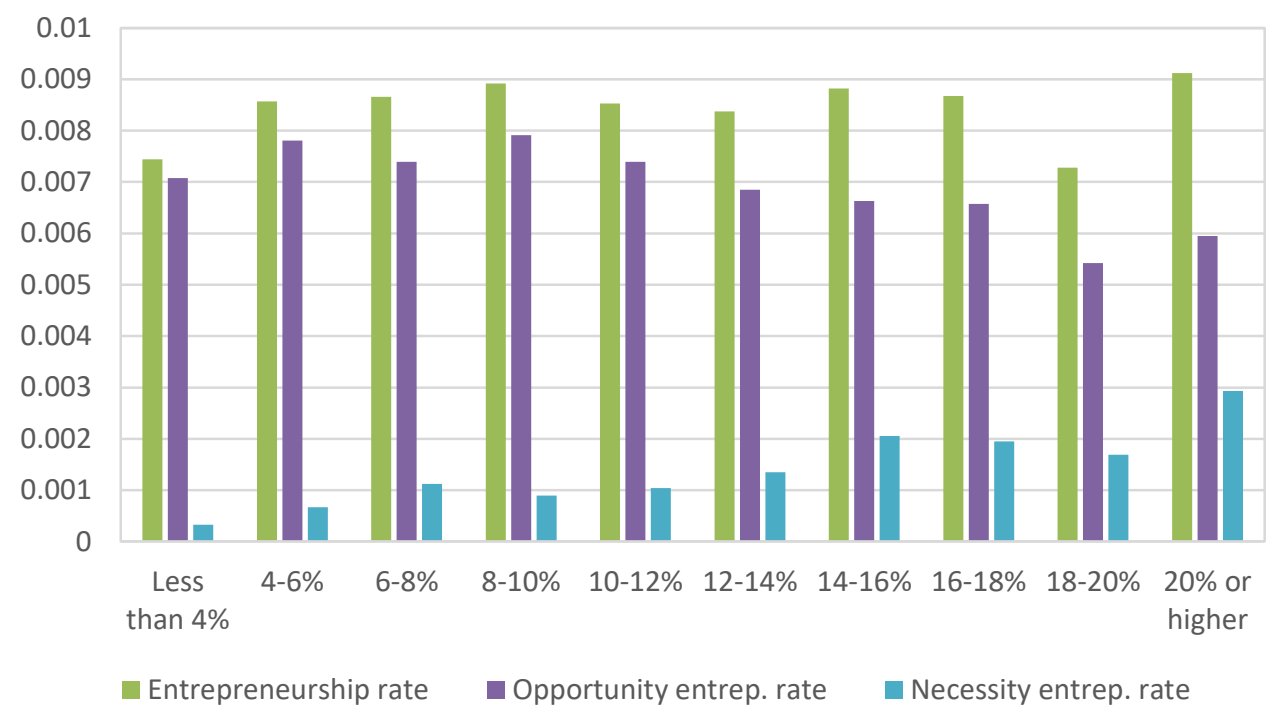

Figure 16

Opportunity Share of New Entrepreneurs by Local Unemployment Rates German Socio-economic Panel (1996-2015)

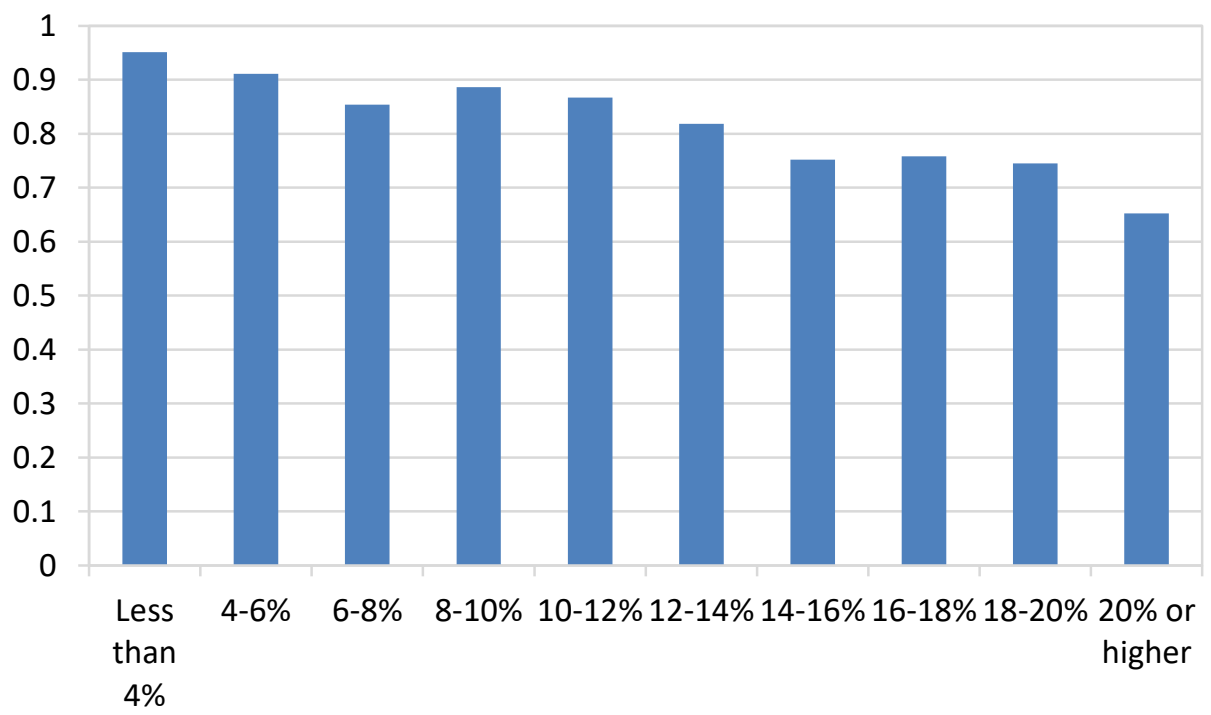


Figure 17

Incorporated Share of New Entrepreneurs and Unemployment Rate (1996-2015)

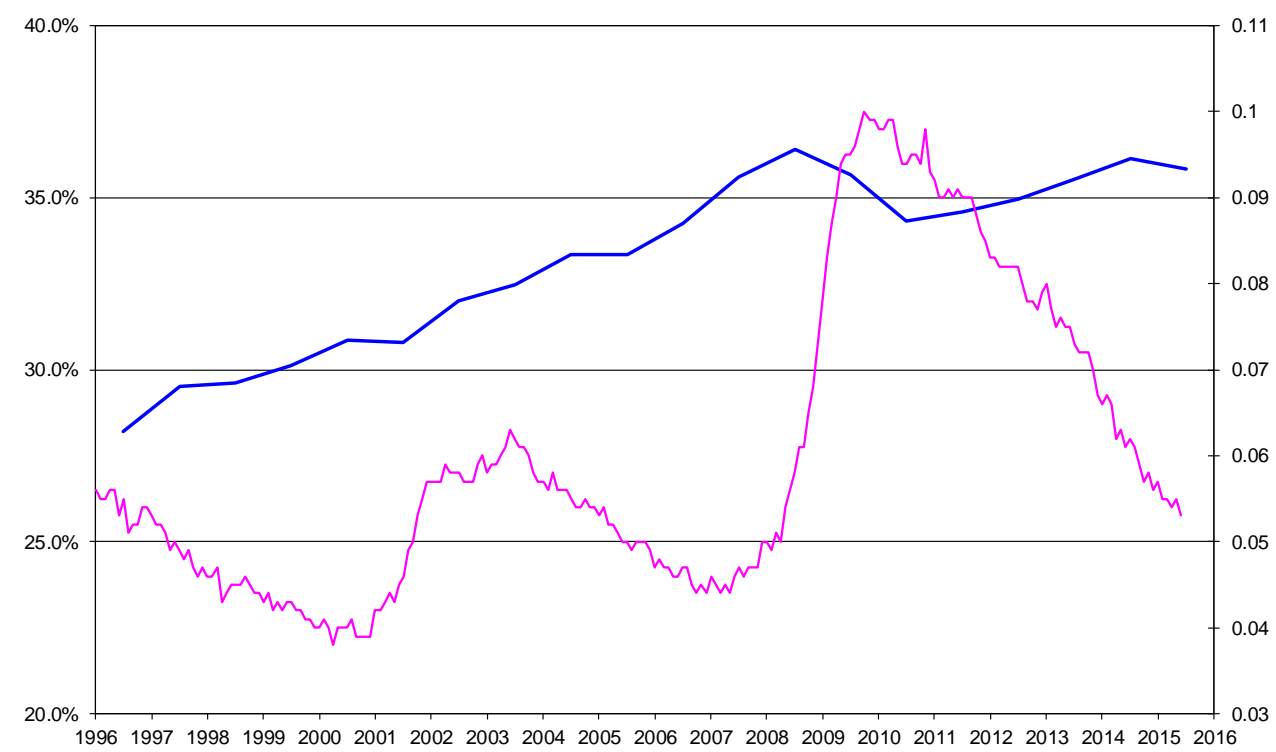


Table 1

Regressions for Probability of Entrepreneurship Type

Current Population Survey (1996-2016)

\begin{tabular}{|c|c|c|c|c|c|c|}
\hline Explanatory Variable & $\begin{array}{c}\text { Total Entrep } \\
\text { (1) }\end{array}$ & $\begin{array}{c}\text { Total Entrep } \\
\text { (2) }\end{array}$ & $\begin{array}{c}\text { Opportunity } \\
\text { Entrep } \\
\text { (3) }\end{array}$ & $\begin{array}{c}\text { Opportunity } \\
\text { Entrep } \\
(4)\end{array}$ & $\begin{array}{c}\text { Necessity } \\
\text { Entrep } \\
(5)\end{array}$ & $\begin{array}{c}\text { Necessity } \\
\text { Entrep } \\
(6)\end{array}$ \\
\hline $\begin{array}{l}\text { National unemployment } \\
\text { rate }\end{array}$ & $\begin{array}{c}0.00574 \\
(0.00176)\end{array}$ & $\begin{array}{c}0.00586 \\
(0.00175)\end{array}$ & $\begin{array}{l}-0.00133 \\
(0.00151)\end{array}$ & $\begin{array}{l}-0.00121 \\
(0.00150)\end{array}$ & $\begin{array}{c}0.00707 \\
(0.00069)\end{array}$ & $\begin{array}{c}0.00707 \\
(0.00069)\end{array}$ \\
\hline Demographic controls & & X & & $\mathrm{X}$ & & $\mathrm{X}$ \\
\hline Regional controls & & $X$ & & $\mathrm{X}$ & & $X$ \\
\hline Urbanicity controls & & $\mathrm{X}$ & & $\mathrm{X}$ & & $\mathrm{X}$ \\
\hline Quadratic time trend & & $x$ & & $x$ & & $x$ \\
\hline Mean of dep. var. & 0.00300 & 0.00300 & 0.00238 & 0.00238 & 0.00062 & 0.00062 \\
\hline Sample size & $11,470,272$ & $11,470,272$ & $11,470,272$ & $11,470,272$ & $11,470,272$ & $11,470,272$ \\
\hline
\end{tabular}

Notes: (1) The sample consists of individuals (ages 20-64) who do not own a business in the initial survey month of the two-month panel. (2) Demographic controls include gender, race, ethnicity, immigrant, age, age squared, education levels, and marital status dummies. (3) Standard errors are clustered at the monthly level. 
Table 2

Regressions for Probability of Entrepreneurship Type

German Socio-economic Panel (1996-2013)

\begin{tabular}{|c|c|c|c|c|c|c|}
\hline & $\begin{array}{c}\text { Total } \\
\text { Entrep. } \\
(1)\end{array}$ & $\begin{array}{c}\text { Total } \\
\text { Entrep. } \\
\text { (2) }\end{array}$ & $\begin{array}{l}\text { Opportunity } \\
\text { Entrep. } \\
\text { (3) }\end{array}$ & $\begin{array}{l}\text { Opportunity } \\
\text { Entrep. } \\
(4)\end{array}$ & $\begin{array}{l}\text { Necessity } \\
\text { Entrep. } \\
\text { (5) }\end{array}$ & $\begin{array}{l}\text { Necessity } \\
\text { Entrep. } \\
(6)\end{array}$ \\
\hline $\begin{array}{l}\text { National unemploy- } \\
\text { ment rate }\end{array}$ & $\begin{array}{c}0.0286 \\
(0.0182)\end{array}$ & $\begin{array}{l}0.0810 \\
(0.0368)\end{array}$ & $\begin{array}{r}0.0105 \\
(0.0159)\end{array}$ & $\begin{array}{r}0.0516 \\
(0.0324)\end{array}$ & $\begin{array}{r}0.0181 \\
(0.0058)\end{array}$ & $\begin{array}{r}0.0294 \\
(0.0112)\end{array}$ \\
\hline Demog. Controls & & $\mathrm{X}$ & & $\mathrm{X}$ & & $\mathrm{X}$ \\
\hline Regional controls & & $x$ & & $\mathrm{X}$ & & $x$ \\
\hline Urbanicity controls & & $x$ & & $x$ & & $x$ \\
\hline Quadrat. time trend & & $\mathrm{X}$ & & $\mathrm{X}$ & & $X$ \\
\hline Mean of dep. var. & 0.0098 & 0.0098 & 0.0083 & 0.0083 & 0.0015 & 0.0015 \\
\hline Sample size & 203,853 & 203,853 & 203,853 & 203,853 & 203,853 & 203,853 \\
\hline
\end{tabular}

Notes: The sample consists of individuals (ages 20-64) who do not own a business in the year of observation. The dependent variable in the first two columns is one if the individual owns a business in the subsequent year and zero otherwise (new entrepreneur). In columns (3) and (4), only those among the new entrepreneurs are counted as new opportunity entrepreneur who are not unemployed in the initial year, and in (5) and (6), those who are unemployed in the initial year are coded as new necessity entrepreneurs. Demographic controls include gender, direct and indirect migration background, age, age squared, educational degrees, and a marital status dummy. Urbanicity is accounted for by including the population density in the Spatial Planning Region. The standard errors in parenthesis are clustered at the level of observation years. We obtain similar results when we run regressions on data aggregated by year (without control variables due to a lack of degrees of freedom), as recommended by Angrist and Pischke (2009) when the number of clusters is small. 
Table 3

Regressions for Probability of Entrepreneurship Type for Local Unemployment Rates

Current Population Survey (1996-2016)

\begin{tabular}{lcccccc} 
& Total Entrep & Total Entrep & $\begin{array}{c}\text { Opportunity } \\
\text { Entrep }\end{array}$ & $\begin{array}{c}\text { Opportunity } \\
\text { Entrep }\end{array}$ & $\begin{array}{c}\text { Necessity } \\
\text { Entrep }\end{array}$ & $\begin{array}{c}\text { Necessity } \\
\text { Entrep }\end{array}$ \\
Explanatory Variable & $(1)$ & $(2)$ & $(3)$ & $(4)$ & $(5)$ & $(6)$ \\
\hline Local unemployment & 0.00852 & 0.00682 & 0.00014 & -0.00105 & 0.00838 & 0.00788 \\
rate & $(0.00141)$ & $(0.00100)$ & $(0.00103)$ & $(0.00075)$ & $(0.00062)$ & $(0.00053)$ \\
Demographic controls & & & & & & \\
Regional controls & & $\mathrm{X}$ & & $\mathrm{X}$ & & $\mathrm{X}$ \\
Urbanicity controls & & $\mathrm{X}$ & & $\mathrm{X}$ & & $\mathrm{X}$ \\
Quadratic time trend & & $\mathrm{X}$ & & $\mathrm{X}$ & & $\mathrm{X}$ \\
Mean of dep. var. & 0.00295 & 0.00300 & 0.00233 & 0.00233 & 0.00062 & 0.00062 \\
Sample size & $8,772,816$ & $8,772,816$ & $8,772,816$ & $8,772,816$ & $8,772,816$ & $8,772,816$ \\
\hline
\end{tabular}

Notes: (1) The sample consists of individuals (ages 20-64) who do not own a business in the initial survey month of the two-month panel. (2) Demographic controls include gender, race, ethnicity, immigrant, age, age squared, education levels, and marital status dummies. (3) Standard errors are clustered at the MSA level. 
Table 4

Regressions for Probability of Entrepreneurship Type for Local Unemployment Rates

German Socio-economic Panel (1996-2013)

\begin{tabular}{|c|c|c|c|c|c|c|}
\hline & $\begin{array}{c}\text { Total } \\
\text { Entrep. } \\
\text { (1) }\end{array}$ & $\begin{array}{c}\text { Total } \\
\text { Entrep. } \\
\text { (2) }\end{array}$ & $\begin{array}{l}\text { Opportunity } \\
\text { Entrep. } \\
\text { (3) }\end{array}$ & $\begin{array}{l}\text { Opportunity } \\
\text { Entrep. } \\
\text { (4) }\end{array}$ & $\begin{array}{l}\text { Necessity } \\
\text { Entrep. } \\
\text { (5) }\end{array}$ & $\begin{array}{c}\text { Necessity } \\
\text { Entrep. } \\
\text { (6) }\end{array}$ \\
\hline $\begin{array}{l}\text { Local unemploy- } \\
\text { ment rate }\end{array}$ & $\begin{array}{c}0.0022 \\
(0.0099)\end{array}$ & $\begin{array}{c}0.0011 \\
(0.0150)\end{array}$ & $\begin{array}{l}-0.0120 \\
(0.0088)\end{array}$ & $\begin{array}{c}-0.0141 \\
(0.0121)\end{array}$ & $\begin{array}{c}0.0142 \\
(0.0022)\end{array}$ & $\begin{array}{c}0.0153 \\
(0.0049)\end{array}$ \\
\hline Demog. controls & & $\mathrm{X}$ & & $\mathrm{X}$ & & $\mathrm{X}$ \\
\hline Regional controls & & $X$ & & $\mathrm{X}$ & & $x$ \\
\hline Urbanicity controls & & $X$ & & $x$ & & $X$ \\
\hline Quadrat. time trend & & $x$ & & X & & $x$ \\
\hline Mean of dep. var. & 0.0098 & 0.0098 & 0.0083 & 0.0083 & 0.0015 & 0.0015 \\
\hline Sample size & 185,300 & 185,300 & 185,300 & 185,300 & 185,300 & 185,300 \\
\hline
\end{tabular}

Notes: The sample consists of individuals (ages 20-64) who do not own a business in the year of observation. The dependent variable in the first two columns is one if the individual owns a business in the subsequent year and zero otherwise (new entrepreneur). In columns (3) and (4), only those among the new entrepreneurs are counted as new opportunity entrepreneur who are not unemployed in the initial year, and in (5) and (6), those who are unemployed in the initial year are coded as new necessity entrepreneurs. The local unemployment rate is the unemployment rate in the Spatial Planning Region (SPR) where the individual lives. Demographic controls include gender, direct and indirect migration background, age, age squared, educational degrees, and a marital status dummy. Urbanicity is accounted for by including the population density in the SPR. The standard errors in parenthesis are clustered at the SPR level. 
Table 5

Mean Characteristics of New Entrepreneurs in their First Month

Current Population Survey (1996-2015)

\begin{tabular}{|c|c|c|}
\hline & $\begin{array}{l}\text { New Opportunity } \\
\text { Entrepreneurs }\end{array}$ & $\begin{array}{l}\text { New Necessity } \\
\text { Entrepreneurs }\end{array}$ \\
\hline Incorporated & $19.1 \%$ & $10.5 \%$ \\
\hline Employer & $14.9 \%$ & $4.6 \%$ \\
\hline Agriculture & $7.4 \%$ & $2.9 \%$ \\
\hline Construction & $17.3 \%$ & $33.0 \%$ \\
\hline Manufacturing & $3.4 \%$ & $2.1 \%$ \\
\hline Wholesale/Retail Trade & $11.8 \%$ & $7.9 \%$ \\
\hline Trans/Utilities & $3.9 \%$ & $4.0 \%$ \\
\hline Information & $1.9 \%$ & $3.2 \%$ \\
\hline Financial Activities & $6.5 \%$ & $4.2 \%$ \\
\hline Professional/Business & $20.0 \%$ & $21.1 \%$ \\
\hline Education/Health & $13.8 \%$ & $8.6 \%$ \\
\hline Leisure/Hospitality & $6.7 \%$ & $5.6 \%$ \\
\hline Other Services & $7.4 \%$ & $7.5 \%$ \\
\hline Sample size & 29,183 & 7,055 \\
\hline
\end{tabular}

Notes: (1) The sample consists of individuals (ages 20-64) who are new entrepreneurs in in the second survey month of the two-month panel. (2) Employer status is only available starting in 2014. 
Table 6

Mean Characteristics of New Entrepreneurs in their First Year

German Socio-economic Panel (1996-2013)

\begin{tabular}{lcc} 
& New Opportunity Entrepreneurs & New Necessity Entrepreneurs \\
\hline Solo entrepreneur & 0.5322 & 0.7516 \\
$1-9$ employees & 0.2684 & 0.1742 \\
10 or more employees & 0.0603 & 0.0097 \\
Full-time & 0.6655 & 0.7645 \\
Monthly gross labor income in euro & 2536 & 1521 \\
Business assets in euro & 49927 & 6974 \\
Industry & & 0.0290 \\
Agriculture & 0.0307 & 0.0000 \\
Mining and quarrying & 0.0006 & 0.0000 \\
Energy and water & 0.0029 & 0.0355 \\
Manufacturing & 0.0377 & 0.1000 \\
Construction & 0.0725 & 0.1484 \\
Trade & 0.1565 & 0.0419 \\
Hotels and restaurants & 0.0406 & 0.0226 \\
Transport and communication & 0.0423 & 0.0548 \\
Financial services & 0.0574 & 0.0000 \\
Real estate & 0.0023 & 0.2032 \\
Business services & 0.1733 & 0.1645 \\
Public and personal services & 0.2128 & 0.1581 \\
Missing information on industry & 0.1171 & \\
\hline Notes: Based on 1725 obseations & & \\
\hline
\end{tabular}

Notes: Based on 1725 observations of new opportunity entrepreneurs and 310 observations of new necessity entrepreneurs in their first year of business (ages 20-64). Gross labor income is based on 1367 (249) observations for new opportunity (necessity) entrepreneurs and business assets on 259 (39) observations. Assets are only observed in 2002, 2007 and 2012. 


\section{Appendix}

Appendix Figure 1

New Opportunity Entrepreneurship Rate and Unemployment Rates (1996-2015)

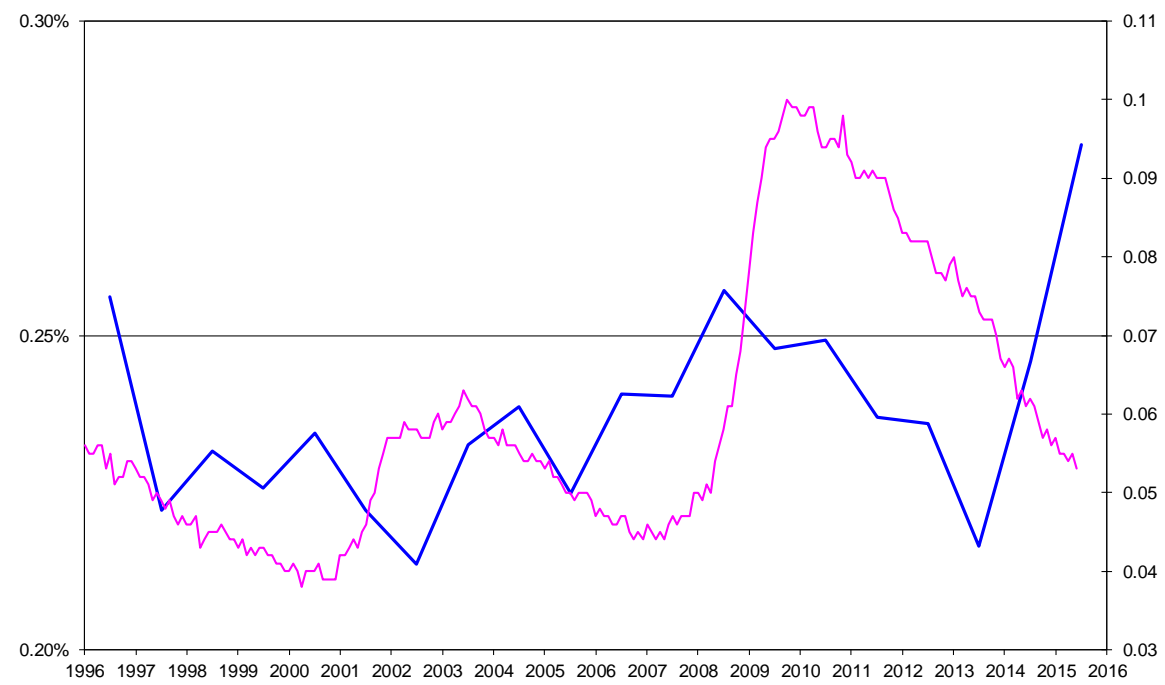

—opportunity Entrepreneurship —Unemployment Rate

Appendix Figure 2

New Necessity Entrepreneurship Rate and Unemployment Rates (1996-2015)

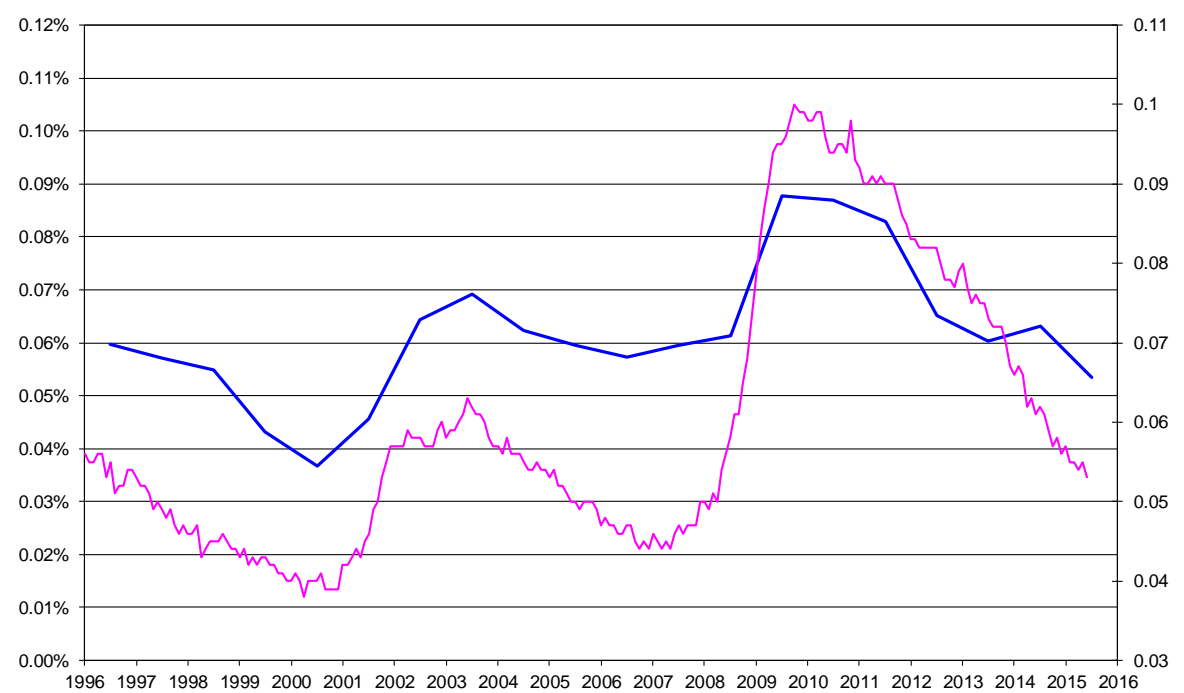


Appendix Figure 3

New Opportunity Entrepreneurship Rate and Unemployment Rates in Germany (1996-2015)

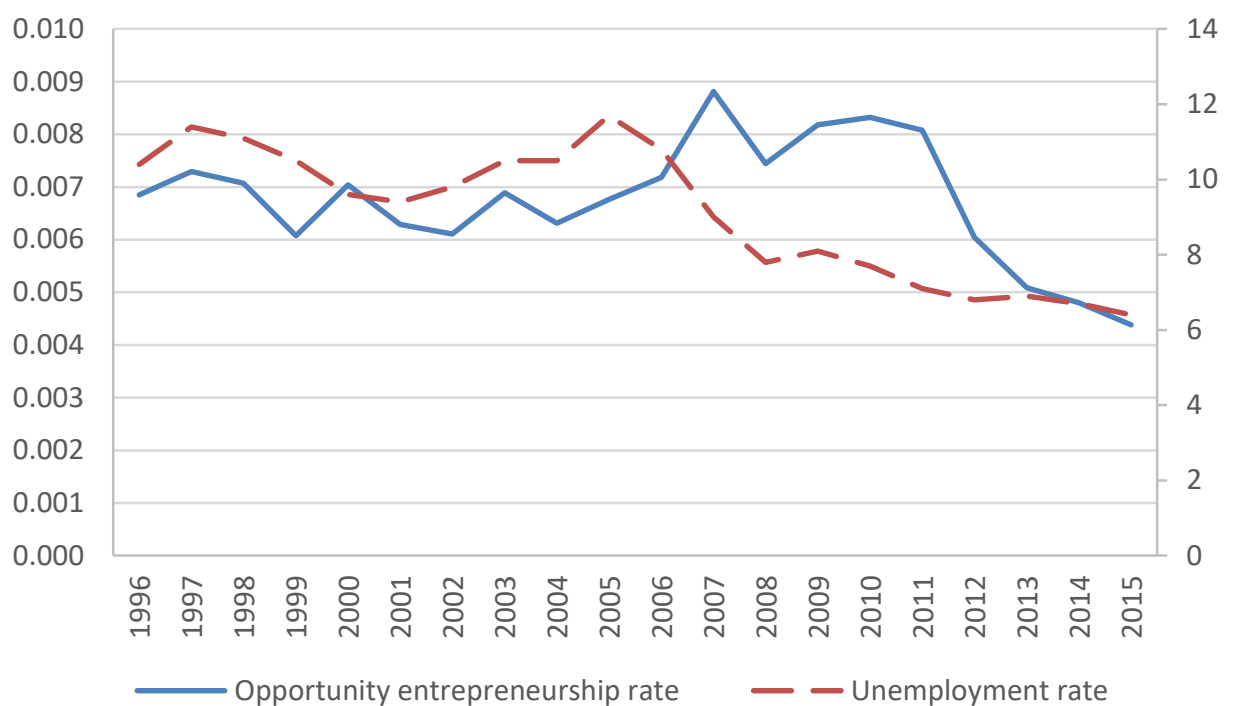

Appendix Figure 4

New Necessity Entrepreneurship Rate and Unemployment Rates in Germany (1996-2015)

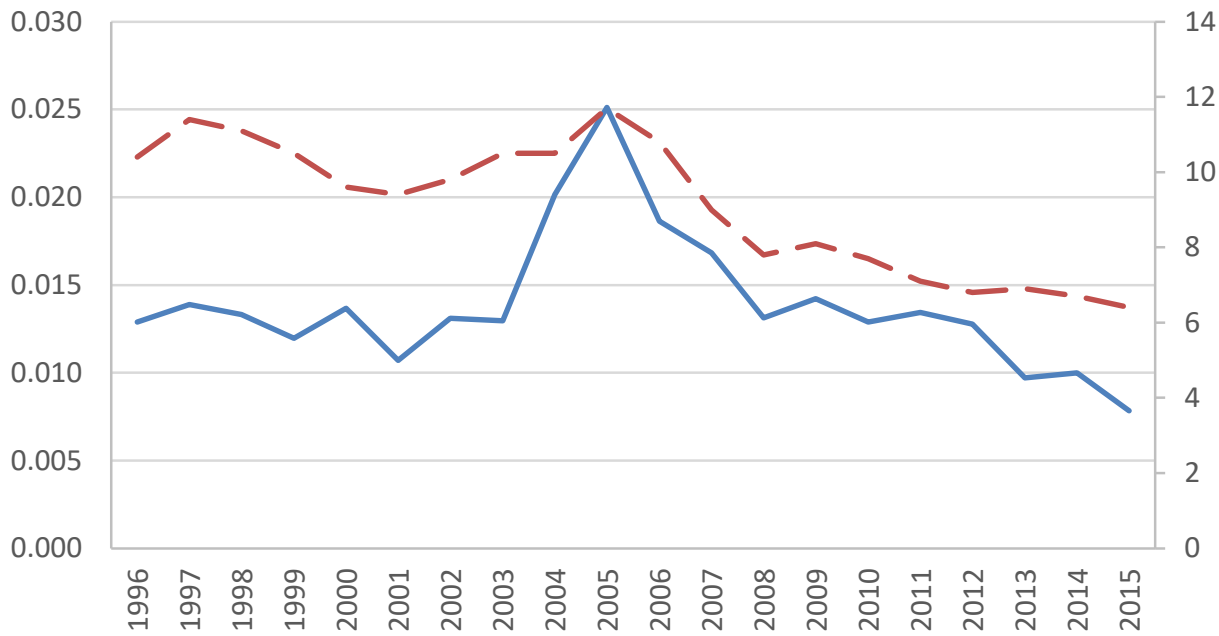

Necessity entrepreneurship rate $\quad-$ Unemployment rate 